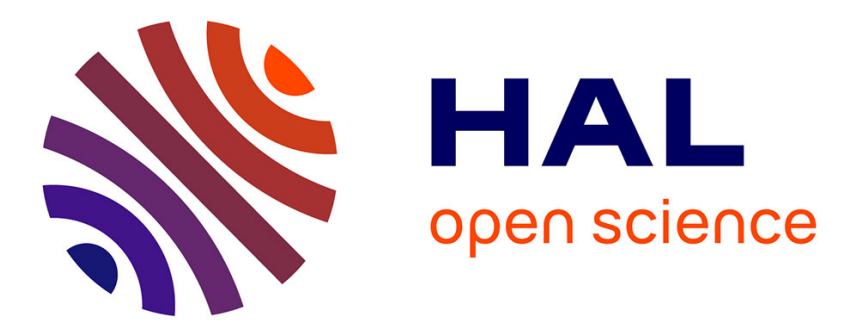

\title{
Interactions between active faulting, volcanism, and sedimentary processes at an island arc: Insights from Les Saintes channel, Lesser Antilles arc
}

\author{
F Leclerc, N. Feuillet, C Deplus
}

\section{- To cite this version:}

F Leclerc, N. Feuillet, C Deplus. Interactions between active faulting, volcanism, and sedimentary processes at an island arc: Insights from Les Saintes channel, Lesser Antilles arc. Geochemistry, Geophysics, Geosystems, 2016, 17, pp.2781 - 2802. 10.1002/2016GC006337 . insu-01467737

HAL Id: insu-01467737

https://hal-insu.archives-ouvertes.fr/insu-01467737

Submitted on 14 Feb 2017

HAL is a multi-disciplinary open access archive for the deposit and dissemination of scientific research documents, whether they are published or not. The documents may come from teaching and research institutions in France or abroad, or from public or private research centers.
L'archive ouverte pluridisciplinaire HAL, est destinée au dépôt et à la diffusion de documents scientifiques de niveau recherche, publiés ou non, émanant des établissements d'enseignement et de recherche français ou étrangers, des laboratoires publics ou privés. 


\section{Geochemistry, Geophysics, Geosystems}

\section{RESEARCH ARTICLE \\ 10.1002/2016GC006337 \\ Key Points: \\ Interactions between active faulting, volcanism, and sedimentary processes at an island arc: Insights from Les Saintes channel, Lesser Antilles arc}

- Identification and characterization of submarine active faults and volcanic features in Guadeloupe (FWI)

- Correlation in time and space between faulting and volcanism with several volcanoes emplaced in damage zones at fault tips

- Sedimentary processes erase faultrelated topography while faulting control their emplacement

Supporting Information:

- Supporting Information S1

Correspondence to:

F. Leclerc,

leclerc@ipgp.fr

Citation:

Leclerc, F., N. Feuillet, and C. Deplus (2016), Interactions between active faulting, volcanism, and sedimentary processes at an island arc: Insights from Les Saintes channel, Lesser Antilles arc, Geochem. Geophys. Geosyst., 17, 2781-2802, doi:10.1002/ 2016 GC006337.

Received 1 MAR 2016 Accepted 25 JUN 2016 Accepted article online 30 JUN 2016 Published online 17 JUL 2016

(c) 2016. American Geophysical Union All Rights Reserved.

\author{
F. Leclerc' ${ }^{1,2}$, N. Feuillet ${ }^{1}$, and C. Deplus ${ }^{1}$ \\ ${ }^{1}$ Institut de Physique du Globe de Paris, Sorbonne Paris Cité, Univ. Paris Diderot, UMR7154, CNRS, Paris, France, ${ }^{2}$ Now at \\ Earth Observatory of Singapore, Nanyang Technological University, Singapore, Singapore
}

\begin{abstract}
New high-resolution marine geophysical data allow to characterize a large normal fault system in the Lesser Antilles arc, and to investigate the interactions between active faulting, volcanism, sedimentary, and mass-wasting processes. Les Saintes fault system is composed of several normal faults that form a $30 \mathrm{~km}$ wide half-graben accommodating NE-SW extension. It is bounded by the Roseau fault, responsible for the destructive Mw 6.3 21 November 2004 earthquake. The Roseau fault has been identified from the island of Basse-Terre to Dominica. It is thus $40 \mathrm{~km}$ long, and it could generate Mw 7 earthquakes in the future. Several submarine volcanoes are also recognized. We show that the fault system initiated after the main volcanic construction and subsequently controls the emission of volcanic products. The system propagates southward through damage zones. At the tip of the damage zones, several volcanic cones were recently emplaced probably due to fissures opening in an area of stress increase. A two-way interaction is observed between active faulting and sedimentary processes. The faults control the development of the main turbiditic system made of kilometer-wide canyons, as well as the location of sediment ponding. In turn, erosion and sedimentation prevent scarp growth at the seafloor. Faulting also enhances mass-wasting processes. Since its initiation, the fault system has consequently modified the morphologic evolution of the arc through perturbation of the sedimentary processes and localization of the more recent volcanic activity.
\end{abstract}

\section{Introduction}

The Lesser Antilles volcanic arc evolves in a complex tectonic regime that results from slip partitioning of the oblique convergence at $2 \mathrm{~cm} / \mathrm{yr}$ between the North and South American plates and the Caribbean plate [Feuillet et al., 2002, Figure 1]. The left-lateral trench parallel component of the convergence is accommodated in the upper plate by two sets of faults: (1) arc-perpendicular normal faults that create graben and halfgraben in the fore arc and (2) arc-parallel normal and oblique faults that crosscut the volcanic arc in an en echelon pattern resulting in left-lateral motion (Figure 1, inset) [Feuillet et al., 2002, 2010].

Along oblique subduction zones where slip partitioning occurs, arc-parallel fault systems are often emplaced along the volcanic arc, as for example in the Aleutian [Lallemant and Oldow, 2000] or in Sumatra [Bellier and Sébrier, 1994; Sieh and Natawidjaja, 2000]. In such tectonic settings, interactions between faulting and volcanism are often poorly documented because (1) onshore, the long-term volcanotectonic history is rarely preserved due to intense weathering and flourishing vegetation that tend to mask or erase reliefs built by tectonic and/or volcanic processes and (2) offshore, we lack high-resolution marine data. However, the interactions between faults, volcanoes, and erosion/sedimentation features inform us about the building, evolution, and destruction of a volcanic arc, and have natural hazard implications.

The Lesser Antilles is an ideal target to document these interactions at several spatial and temporal scales for two reasons: (1) it is almost entirely below sea level and (2) we have an exceptional marine data set with resolution rarely reached in other arcs worldwide. In particular, the occurrence of one of the strongest earthquakes to have occurred on the French territory in the last few decades, a magnitude 6.3 earthquake, on 21 November 2004 in Guadeloupe, French West Indies [Beauducel et al., 2005; Salichon et al., 2009; Bazin et al., 2010; Feuillet et al., 2011] (Figures 1a and 1b), presented us with the unique opportunity to acquire a large panel of high-resolution marine data in the Les Saintes channel during the GWADASEIS and BATHYSAINTES cruises, in 2009 and 2010, respectively. 


\section{QAGU Geochemistry, Geophysics, Geosystems}

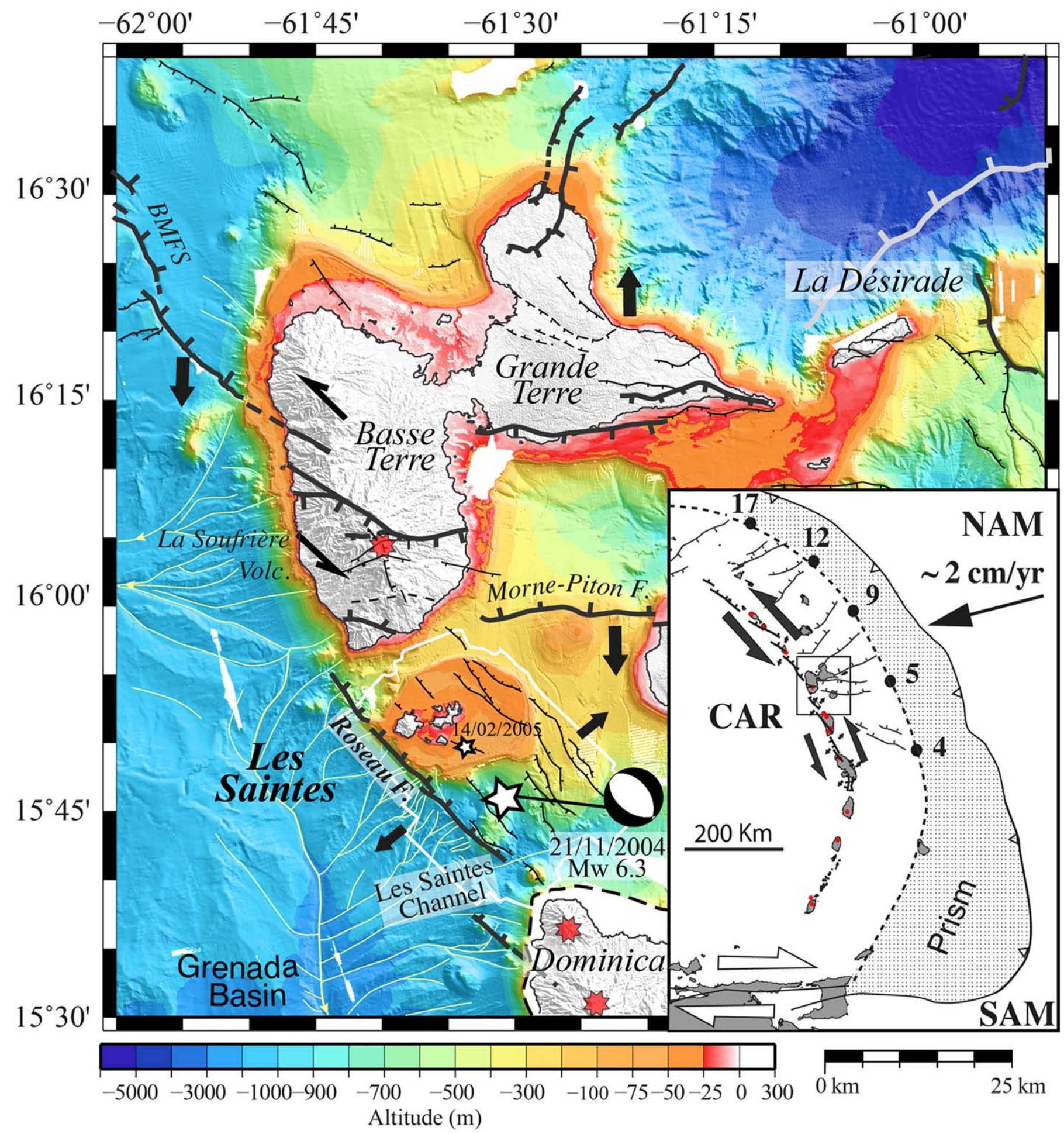

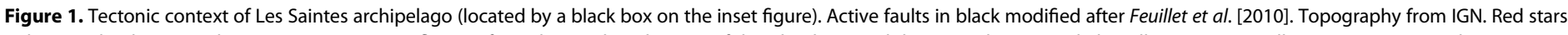
indicate onland active volcanic centers. Canyons flowing from the windward coasts of the islands toward the Grenada Basin in light yellow. BMFS: Bouillante-Montserrat Fault System. Bathymetry from the $50 \mathrm{~m}$ DEM. BATHYSAINTES area encircled by a white line. Location (white stars) of the Mw 6.3 Les Saintes earthquake, associated with focal mechanism, and main

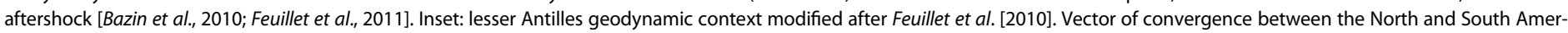

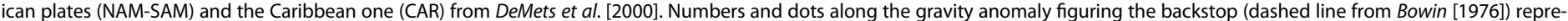
sent the trench parallel component of shear that increases from 4 to $17 \mathrm{~mm} / \mathrm{yr}$ between Martinique and Saba, after López et al. [2006] and Feuillet et al. [2010]. 


\section{QAGU Geochemistry, Geophysics, Geosystems}

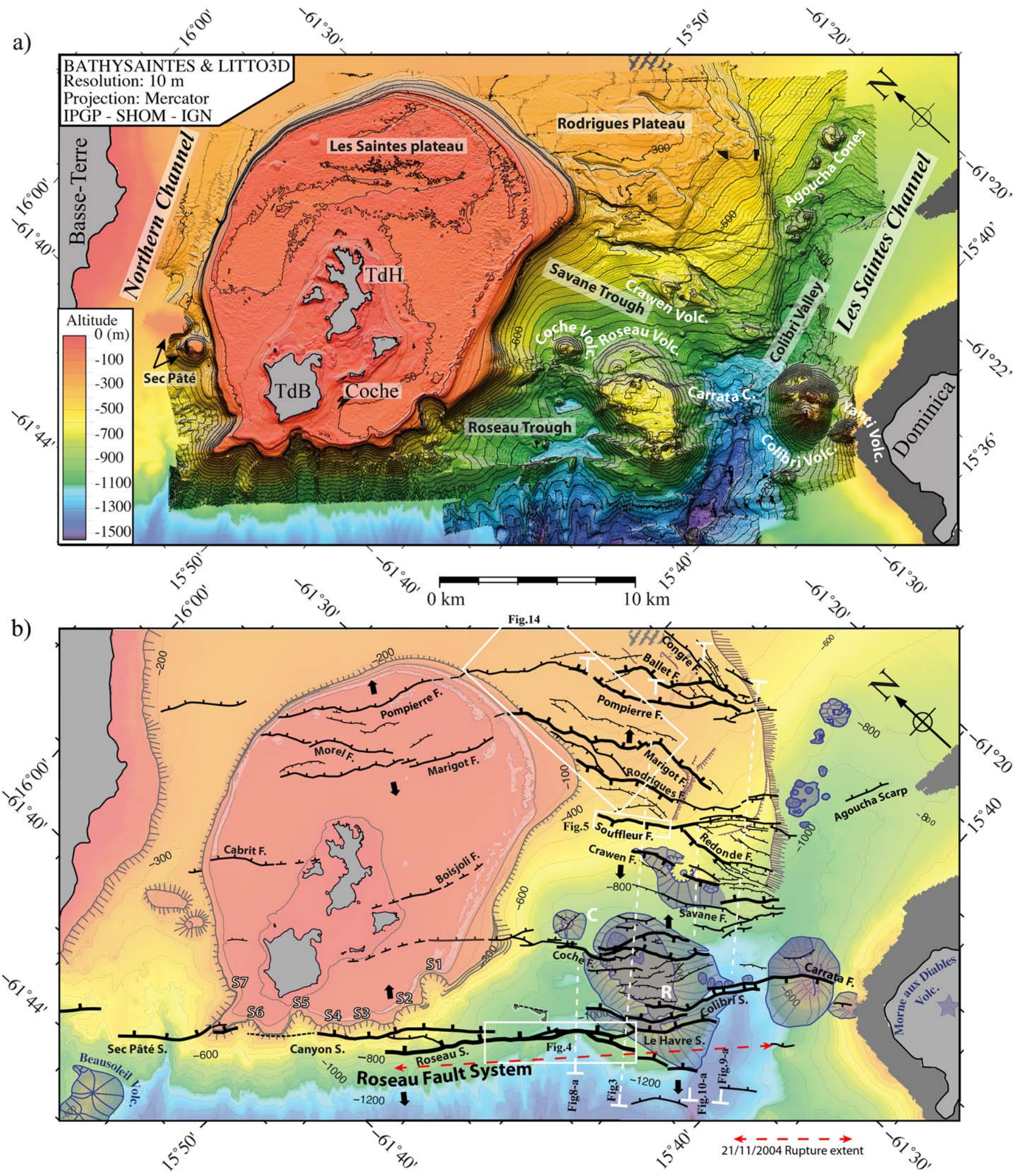

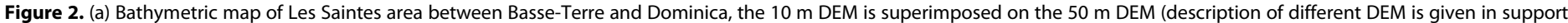
ing information). Isobaths every $10 \mathrm{~m}$, main lines every $50 \mathrm{~m}$. Islands are in grey. (b) Tectonic and morphologic map of Les Saintes area. The bathymetry is from the $50 \mathrm{~m}$ DEM, isobaths every $100 \mathrm{~m}$. Fault scarps with clearest morphological evidence of recent activity are in black, with thicker traces for higher scarps; less clearly active faults in dashed black lines. The dashed red line shows the extent of the Les Saintes 21 November 2004 earthquake rupture, drawn after the slip model of Feuillet et al. [2011]. Submarine volcanoes are represented in

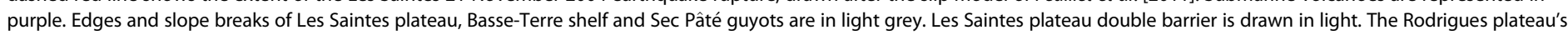
escarpments and slope breaks on its surface unrelated to faulting are in dark red. Twin thick arrows indicate direction of extension. 
The high-resolution swath bathymetry and backscatter imagery complemented by subbottom profiler data and high-resolution 72 channel seismic reflection profiles gathered during the cruises allow us to identify and characterize the fault system, the volcanic centers, as well as sedimentary processes throughout the Les Saintes channel. Analysis of particular markers such as submerged reefs, volcanic edifices, and deep sediment waves and canyons allowed us to place bounds on fault slip rates in some places. We also present here high-resolution side-scan sonar images on submarine active faults that reveal their complex morphology. Based on the overall data set, we discuss the link between faulting, volcanism, and sedimentary processes at several spatiotemporal scales and highlight their implication for morphologic evolution of the volcanic arc as well as for seismic and tsunami hazard assessment in this area.

\section{Data Collection and Analysis}

The GWADASEIS and BATHYSAINTES cruises were conducted in February-March 2009 on the N/O Le Suroit (Ifremer), and in February 2010 on the N/O Pourquoi Pas? (Ifremer, SHOM-French Navy), respectively (supporting information Figure S1).

During the GWADASEIS expedition, we acquired Simrad EM300 swath bathymetry and backscatter data, chirp subbottom profiles, 72 channels seismic reflection profiles, and very high-resolution $(2.5 \mathrm{~m})$ imagery using a French deep-towed side-scan sonar (named SAR for "Système Accoustique Remorqué," device composed of two antennas, $170 \mathrm{kHz}$ for the port side antenna, $190 \mathrm{kHz}$ for the starboard one). Navigation used GPS with no degradation, allowing for positioning accuracy of a few meters.

Ship bathymetry and backscatter data as well as side-scan sonar data were processed using the CARAIBES and SONARSCOPE software developed by Ifremer. Digital elevation models (DEM) were constructed with a horizontal resolution of $25 \mathrm{~m}$. Side-scan sonar images, with resolution of $2.5 \mathrm{~m}$, were geolocalized. The 72 channels seismic reflection data were filtered, stacked, and migrated using the Seismic Unix software [Stockwell and Cohen, 2002]. A NMO correction was applied. The vertical resolution of the seismic data is a few meters. To estimate depths and thicknesses on seismic profiles, we used a velocity of $1500 \mathrm{~m} / \mathrm{s}$ for sea water and $2000 \mathrm{~m} / \mathrm{s}$ within the reef plateau [Searle et al., 1981]. We used a velocity of $1800 \mathrm{~m} / \mathrm{s}$ for sedimentary cover, consistent with the mean velocity value of the first $500 \mathrm{~m}$ of sediments of the 1-D velocity model obtained in the Kahouanne basin, between Guadeloupe and Montserrat [Shalev et al., 2010], and $2000 \mathrm{~m} / \mathrm{s}$ for the outer part of volcanic edifices, as modeled in Montserrat by Paulatto et al. [2010].

During the BATHYSAINTES cruise, we acquired very high-resolution bathymetry (Figure 2) and backscatter data with three multibeam echo sounders used for different seafloor depths: Reson Seabat 7150 (mode $24 \mathrm{kHz}$ ) between 200 and $2000 \mathrm{~m}$ bsl; Reson Seabat 7111 between 20 and $200 \mathrm{~m}$ bsl and Kongsberg EM3002 between 0 and $30 \mathrm{~m}$ bsl. A tide gauge was installed in Terre-de-Haut, Les Saintes archipelago, for the duration of the cruise in order to obtain a good tidal model. Chirp subbottom profiles were collected as well. Navigation used DGPS allowing a positioning accuracy of about $1 \mathrm{~m}$. Bathymetry and backscatter data were processed using the CARAIBES software. The quality of this new bathymetry data allows for the construction of DEMs with resolutions of 5 and $10 \mathrm{~m}$ on Les Saintes plateau and the whole surveyed area, respectively. The vertical accuracy of the bathymetric data is about $0.1-0.2 \%$ of the depth, namely $2 \mathrm{~m}$ at $1000 \mathrm{~m}$ bsl. A $6 \mathrm{~m}$ mosaic of backscatter data was also calculated (supporting information Figure S2).

The new data set was complemented with older bathymetry and seismic data of the 1998 AGUADOMAR cruise [Deplus et al., 2001], and by the LITTO3D ${ }^{\circledR}$ bathymetry LiDAR survey (2011, IGN/SHOM) for the 0-30 m bsl depth range (see Table 1 and Figure S1, supporting information).

\section{Results}

\subsection{Seafloor Morphology}

One of the main geological features of the Les Saintes area is a large $23 \mathrm{~km}$ wide plateau, lying at $45 \mathrm{~m}$ depth bsl (Figure 2) and made of several stacked reef units probably drowned during the last sea level rise, $10.5 \pm 0.5 \mathrm{ka}$ ago [Leclerc et al., 2014]. This plateau is surrounded by two deep channels (Figure 2 and supporting information Figure S2). The northern one is flat, $250 \mathrm{~m}$ deep and $5 \mathrm{~km}$ wide, with two shoals lying at $\sim 100 \mathrm{~m} \mathrm{bsl}$ (Sec Pâté) inside. The southern one is deeper (1300 m bsl) and has a more complex morphology. Numerous submarine volcanoes have been emplaced there (Coche, Roseau, Carrata cones, Colibri, 


\section{QAGU Geochemistry, Geophysics, Geosystems}

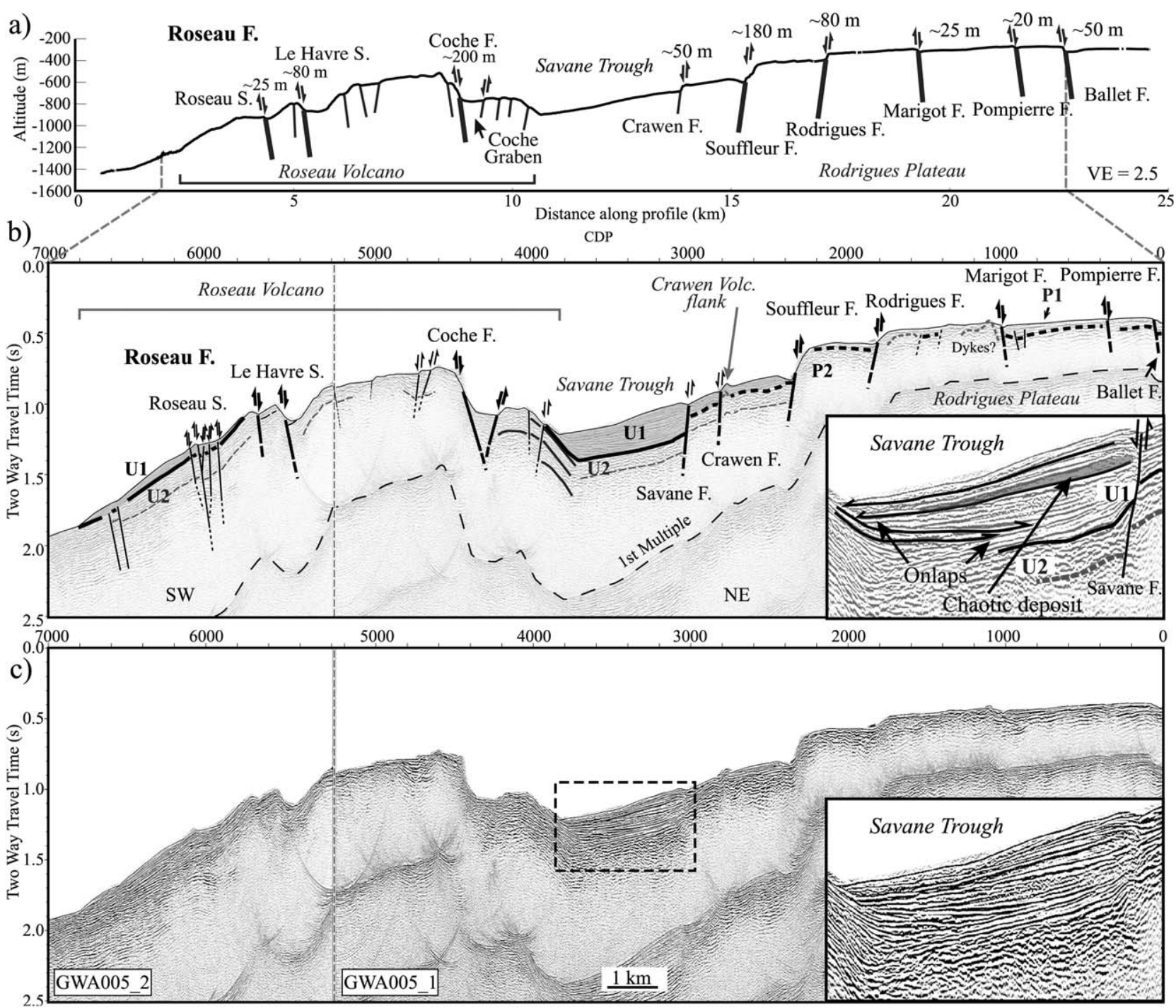

Figure 3. Les Saintes graben imaged by the perpendicular 72 channels seismic profile GWA005 (located in Figure $2 \mathrm{~b}$ by white brackets). (a) Bathymetric profile of the graben and horst, obtained from the $10 \mathrm{~m}$ DEM along the seismic profile. (b) Interpretation and (c) seismic data. Faults in black. See text for unit description. CDP: common depth point. Inset: close-up view of the Savane trough.

Yanti, etc.) mostly in a NW-SE direction between the main onland volcanic centers of Les Saintes (Terre-deHaut and Terre-de-Bas) and Dominica. The bathymetry is also disrupted by numerous, several kilometers long and several tens to one hundred meters high normal fault scarps parallel to the volcanic arc. These faults dissect volcanoes, separate tilted blocks of the Rodrigues deep plateau, and extend onto the Les Saintes reef plateau. They constitute the Les Saintes fault system.

\subsection{Les Saintes Fault System}

The main fault of the system is the eastward dipping $\mathrm{N} 130^{\circ} \mathrm{E}$ striking Roseau fault (Figure $2 \mathrm{~b}$ ). It has been identified to be responsible for the magnitude 6.3 earthquake of 21 November 2004 [Bazin et al., 2010; Feuillet et al., 2011]. High-resolution bathymetry and backscatter data collected during BATHYSAINTES show that the Roseau fault extends from the northern coast of Dominica to the southern coast of Basse-Terre and is thus $40 \mathrm{~km}$ long. It crosscuts the Colibri volcano, the Colibri valley, the Roseau volcano, the western slope of

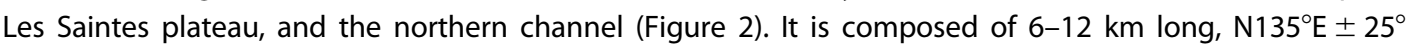
striking segments (named Colibri, Le Havre, Roseau, Canyon, and Sec Pâté segments, from south to north, Figure 2 and supporting information Figure S3) that have scarps of up to $200 \mathrm{~m}$ high and arranged in leftlateral echelons to the south and right-lateral echelons to the north. 
a)

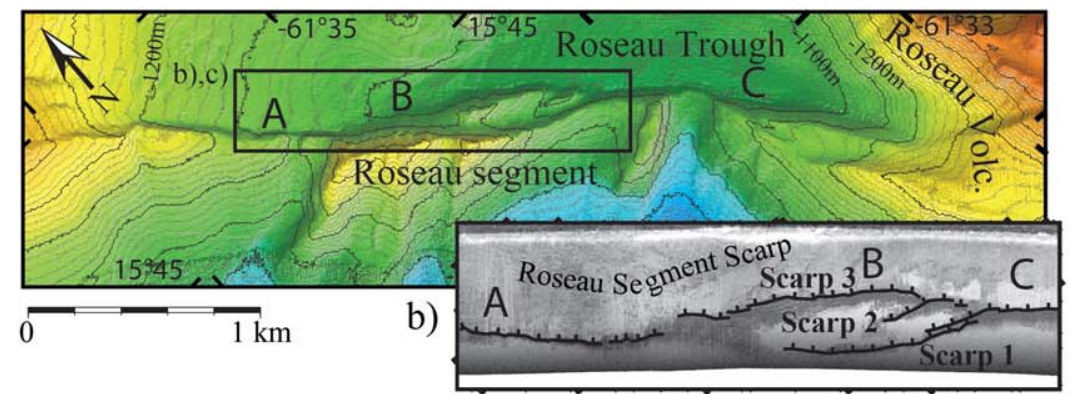

c)
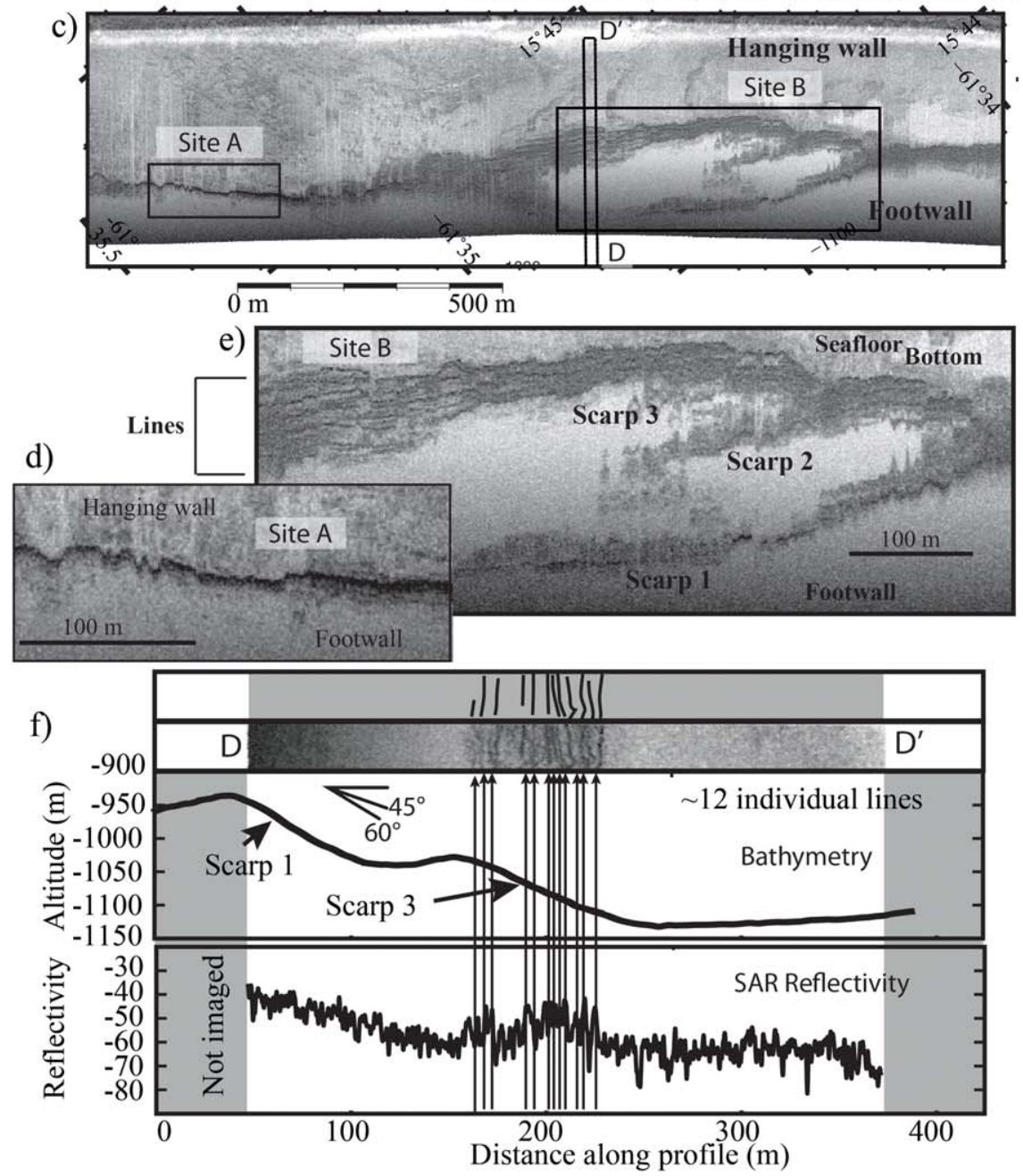

Figure 4. Details of Roseau segment escarpment, located in Figure 2b. (a) Bathymetry of the Roseau segment, isobaths every $20 \mathrm{~m}$; (b) detailed fault map of the Roseau segment on the SAR image enlarged in Figure 4c, the darker the more reflective. (d, e) Close-up of the SAR image on sites A and B. (f) Comparison between SAR image: (top) interpretation and data, (middle) bathymetry, and (bottom) SAR reflectivity along $\mathrm{DD}^{\prime}$ profile perpendicular to the scarp. Black and white alternations creating lines identified in the SAR image, correlated to bathymetry and reflectivity by black arrows. As the SAR is a deep-towed acoustic system driven at few tens of meters above the seafloor, the highest part of the scarp is not imaged (grey area).

Several other smaller antithetic normal faults parallel the Roseau fault and dissect its hanging wall (Rodrigues plateau). The major ones (Redonde, Souffleur, and Rodrigues) strike $\sim \mathrm{N} 150^{\circ} \mathrm{E}$, are $5-10 \mathrm{~km}$ long and have scarps up to $150 \mathrm{~m}$ high. They are arranged in right-stepping echelons with other smaller faults (Savane, Crawen) along a $\sim \mathrm{NO}^{\circ} \mathrm{E}$ direction, implying a sinistral component of motion in this direction (Figure 2 and supporting information Figure S4). Southward, the deformation is much more distributed along numerous kilometer long secondary faults with smaller scarps (up to $30 \mathrm{~m}$ ) and organized in horsetail structures, secondary branches, and echelons (Figure 2 and supporting information Figure S5). 


\section{QAGU Geochemistry, Geophysics, Geosystems}
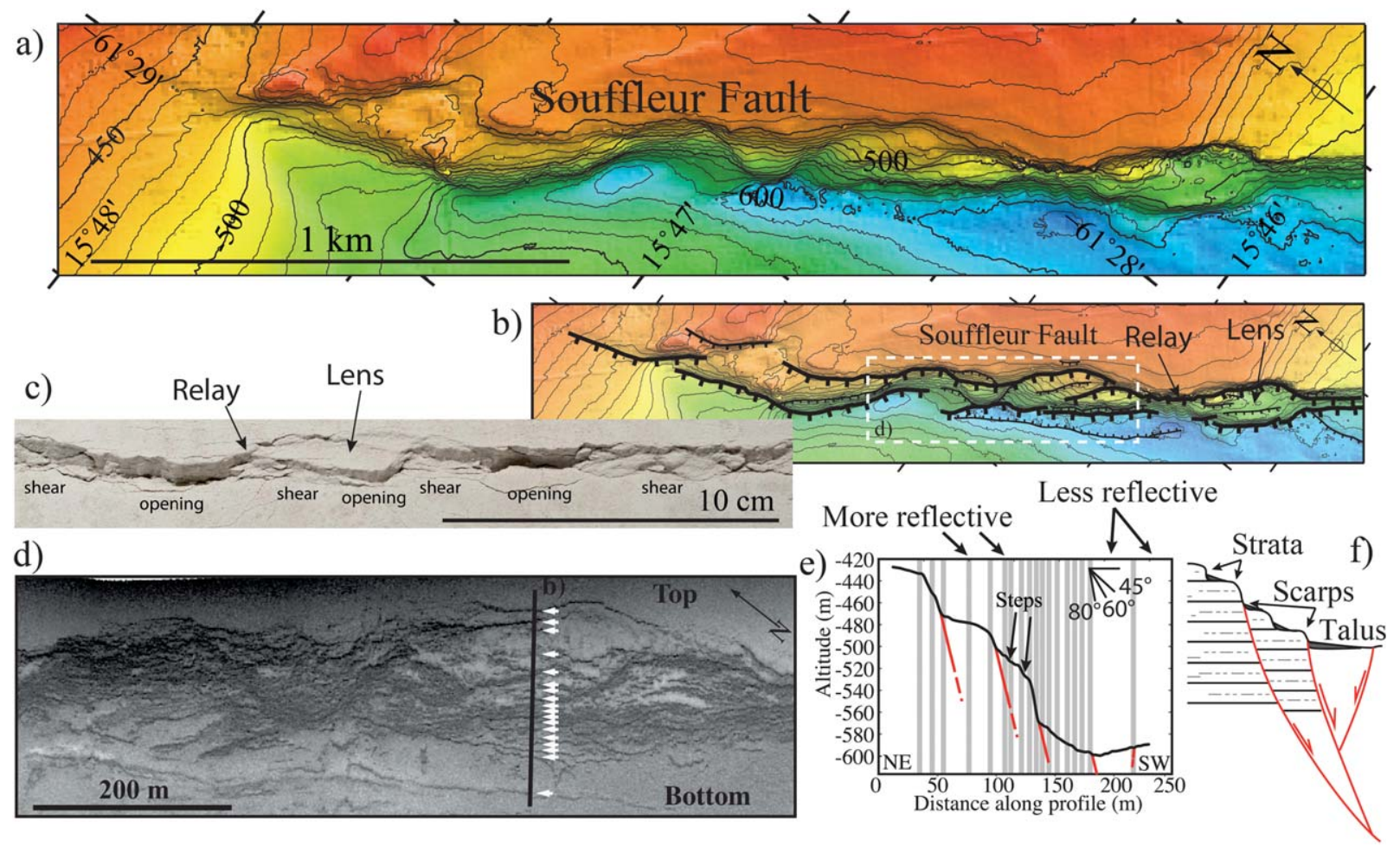

Figure 5. The morphology of Souffleur scarp at different scale. (a) Bathymetric map of the scarp, isobaths every $10 \mathrm{~m}$, main lines every $50 \mathrm{~m}$, located in Figure $2 \mathrm{~b}$. (b) Detailed map of the escarpment evidencing hundred meters scale along strike complexities. (c) Comparison with Kettermann and Urai [2015]'s experiments reproducing hybrid failure showing alternating patches of opening and shear fractures [Kettermann and Urai, 2015, Figure 6b]. (d) A close-up view of the scarp morphology is available thanks to SAR images, location in Figure 5b. Black and white alternations forming lines can be followed on several meters to hundred meters along strike. Black ones (high reflectivity) are identified by white arrows and reported with grey lines on the bathymetry profile shown in Figure $5 \mathrm{e}$. They do not correspond to small-scale bathymetric features imaged in our bathymetric data, indicating that the features imaged in the SAR data are smaller than $10 \mathrm{~m}$. They could correspond to fault plane and strata, as schematized in Figure $5 \mathrm{f}$.

Farther east, another set of normal faults dips to the east. The Marigot, Pompierre, and Ballet are up to $30 \mathrm{~km}$ long, strike NS, and have scarps of several tens of meters high (Figure 2, topographic profile of Figure $3 \mathrm{a}$, and supporting information Figure S4). They structure a right-stepping en echelon array along the $\mathrm{N} 135^{\circ} \mathrm{E}$ direction (Figure $2 \mathrm{~b}$ ). To the north, they extend onto the Les Saintes plateau (Figure $2 \mathrm{~b}$ ) where they have very clear expression and offset the post-Last Glacial Maxima (post-LGM) reef by 5-8 $\mathrm{m}$ (see description in Leclerc et al. [2014], Figure 2 and supporting information Figure S6). To the south, these faults branch into numerous smaller secondary $\sim \mathrm{N} 15^{\circ} \mathrm{E}$ striking faults (i.e., Congre Fault, Figure $2 \mathrm{~b}$ ).

Apart from the Roseau fault, all scarps decrease in height southward, and finally disappear beyond the Rodrigues plateau escarpment in the ENE-WSW striking, 800-1300 m deep, $3 \mathrm{~km}$ wide Colibri valley. No faults could be identified there, either in bathymetry, backscatter imagery nor on seismic profiles. The fault system may simply terminate at this location. This would be consistent with the seismological data, as no aftershocks of the 21 November 2004 event have been recorded in the Colibri valley [Feuillet et al., 2011]; and with the fault system morphology, as horsetail systems (also named tip splay faults) are systematically observed at the end of propagating structures [e.g., Perrin et al., 2016].

\subsection{Small-Scale Morphology of Scarps}

Cumulative scarps of several hundred meters are exposed in Les Saintes channel. High-resolution data highlight their complex morphology that can be related to failure mode [e.g., Kettermann and Urai, 2015], erosion, and sedimentation processes, and constitutes insights into the fault's seismic cycle history [e.g., Armijo et al., 2005]. Side-scan sonar imagery allowing a metric horizontal resolution on deep submarine faults is rare and only few studies exist on small-scale morphologic features of faults scarps offshore [Armijo et al., 2005; Elias et al., 2007]. In Marmara Sea, such data have been combined with microbathymetry to describe the relationship between the cumulative scarp and the imaged individual coseismic scarps, to hypothesize about earthquake recurrence on submarine faults [Armijo et al., 2005]. Onshore, such morphology showing 
individual coseismic scarp is never preserved as weathering and erosion processes degrade a scarp as soon as it is created [Wallace, 1977]. Offshore, in the absence of weathering, erosion processes differ and the fault scarps may be better preserved. Understanding of complex and poorly known interactions between all processes occurring in the submarine environment and contributing to cumulative scarp growth and destruction is beyond the scope of this paper because other data such as microbathymetry and direct observations would be required. It is interesting, however, to compare our observations on small-scale morphology of scarps to other studies.

In Les Saintes channel, the Roseau fault scarp extends from the Roseau volcano to the Les Saintes reef plateau's slopes (Figures 2 and 4a). In the bathymetry, its cumulative scarp dips by about $50^{\circ}$ (Figure $4 \mathrm{f}$ ) and its trace is more simple: the deformation is localized along a unique cumulative scarp reaching up to $200 \mathrm{~m}$ high (zone $A$ and $C$, Figure $4 a$ ) except in its central part (zone B). There, the fault trace splits into three en echelon subscarps of $40 \mathrm{~m}$ (scarp 1), $10 \mathrm{~m}$ (scarp 2), and $40 \mathrm{~m}$ (scarp 3) high where they overlap, for a total throw of $90 \mathrm{~m}$ (Figures $4 \mathrm{a}$ and $4 \mathrm{~b}$ ). The Souffleur antithetic fault scarp shows different small-scale features (Figures $5 \mathrm{a}$ and $5 \mathrm{~b})$. Bathymetric map and profiles perpendicular to the fault direction show that it is composed of smaller, $70^{\circ}-80^{\circ}$ dipping $10-90 \mathrm{~m}$ high scarps undulating in plane view at a scale of several hundred meters (Figures $5 \mathrm{a}$ and $5 \mathrm{~b}$ ). There are also lens structures and relays. Small antithetic faults branch to the main Souffleur fault forming small basins at the base of the scarp. The overall geometry of the Souffleur scarp strikingly resembles a normal fault scarp resulting from hybrid failure (tensile and shear) as reproduced by analogue models [Kettermann and Urai, 2015] (Figure 5c). This rupture mode results in strong segmentation of the scarp, with segments having different strikes and steep dips close to $90^{\circ}$. The scarps of Rodrigues and Marigot faults also exhibit such morphologies and are bordered by small troughs at the base of the main scarps (supporting information Figure S4) that resemble extension fracture opened in a tensile failure mode near the surface. On the contrary, the simpler morphology of Roseau fault scarp indicates that it would result from shear failure [Kettermann and Urai, 2015], a rupture mode producing less steep scarps and narrower fault zones.

During Gwadaseis cruise, the side-scan sonar (named SAR afterward) was towed at 70-100 m above the seafloor along profiles close and parallel to the main faults. The fault scarps, that display steeper slopes than the surrounding terrains, are highly reflective and can be clearly imaged (Figures $4 b-4 e$ and $5 d$ ). The along strike variations in the scarp geometry are particularly well imaged both along Roseau fault (sites $\mathrm{A}$ and B, Figures $4 \mathrm{~d}$ and $4 \mathrm{e}$ ) and Souffleur fault (Figure $5 \mathrm{~d}$ ). The SAR data reveal even more smaller scale features on the scarps: several clear alternations of black (high reflectivity) and white (low reflectivity) subparallel lines are imaged (12 lines can be identified in zones D-D', Figures $4 a$ and $4 \mathrm{e}$, for example). The black lines may correspond to steep slopes in between flatter areas, yielding to staircase morphology for the overall scarps. The lines width being $\sim 5 \mathrm{~m}$ at most on the Roseau scarp, the resolution of our bathymetry data set is too low to confirm such an interpretation (Figure 4e). However, along Souffleur scarp, similar lines are sometimes associated with small few meters high steps in the bathymetry (Figure $5 \mathrm{e}$ ) that favors such an interpretation.

In Marmara, linear features of high reflectivity along scarp have been interpreted as fault free faces made of one or several coseismic scarps [Armijo et al., 2005]. The alternating highly reflective lines parallel to the cumulative scarps, identified in Les Saintes, could therefore correspond to coseismic scarps but also to geological strata (Figure 5f). The lower step, at the base of the Roseau fault scarp, may have partly been generated by the 21 November 2004 rupture [Escartín et al., 2016].

\subsection{Submarine Volcanoes and Interaction With Faulting}

We identified several submarine volcanic centers in the Les Saintes channel. They present more or less preserved morphology suggesting different times of emplacement. The largest is the $4 \mathrm{~km}$ wide, $600 \mathrm{~m}$ high Roseau volcanic complex (Figures $6 \mathrm{a}-6 \mathrm{c}$ ). It has a very flat summit, lying at $\sim 600 \mathrm{~m}$ bsl, topped by small domes and cones up to $100 \mathrm{~m}$ high. It is dismembered by normal faulting, similar to a certain extent to the Fieale volcano in Asal Rift [De Chabalier and Avouac, 1994], and is elongated in a $\sim 225^{\circ}$ E direction. The main Roseau fault offsets its western flank by up to $80 \mathrm{~m}$. Five small vents (Carrata cones), up to $70 \mathrm{~m}$ high and particularly reflective in the backscatter image (Figure $6 \mathrm{~b}$ ), aligned parallel to the fault and were probably emplaced along a fissure accommodating the extension on the southern flank of the volcano.

To the south, the Colibri volcano $(2.5 \mathrm{~km}$ wide, $1 \mathrm{~km}$ high, and composed of two major domes, rising at about $155 \mathrm{~m} \mathrm{bsl}$ ) and the Yanti volcano (500 m high and $800 \mathrm{~m}$ wide) display well preserved morphology 


\section{QAGU Geochemistry, Geophysics, Geosystems}

Roseau Volcano

a)

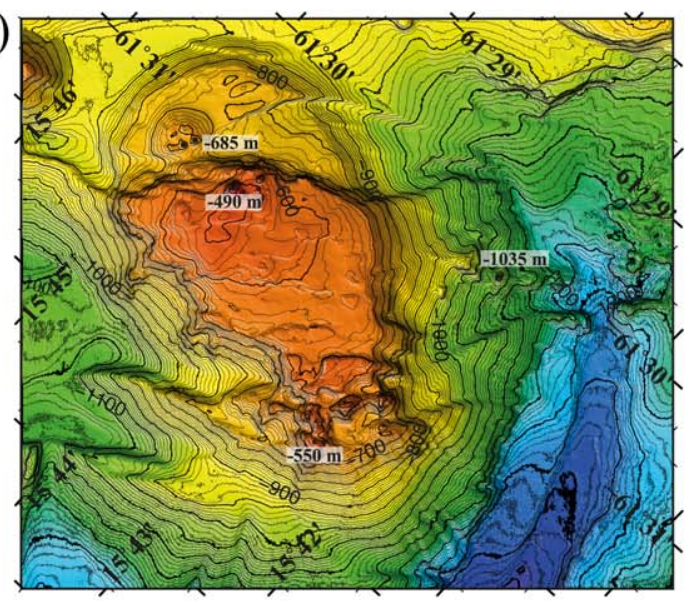

b)

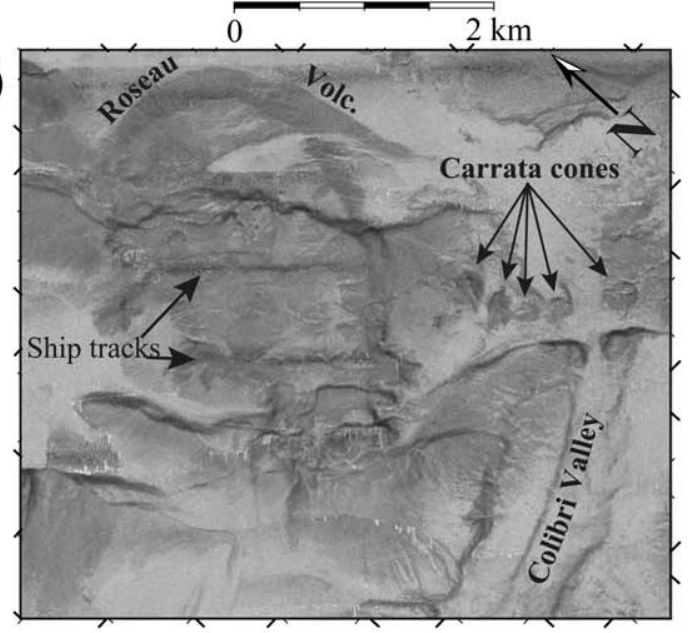

c)

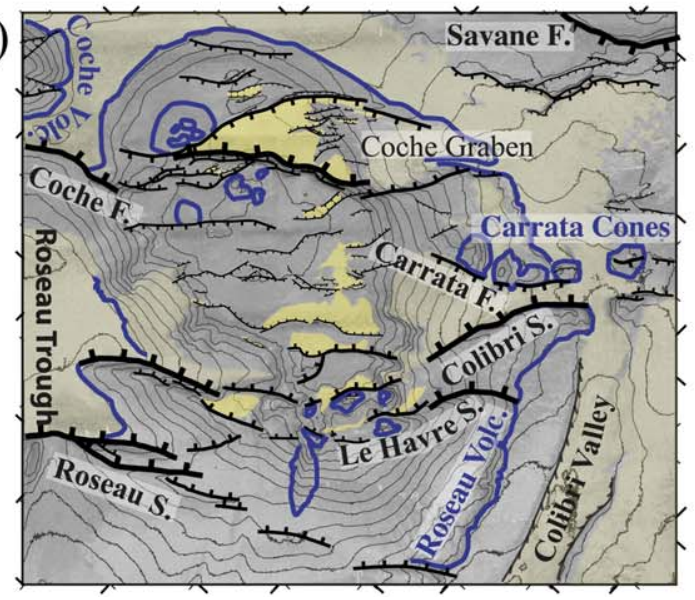

d)

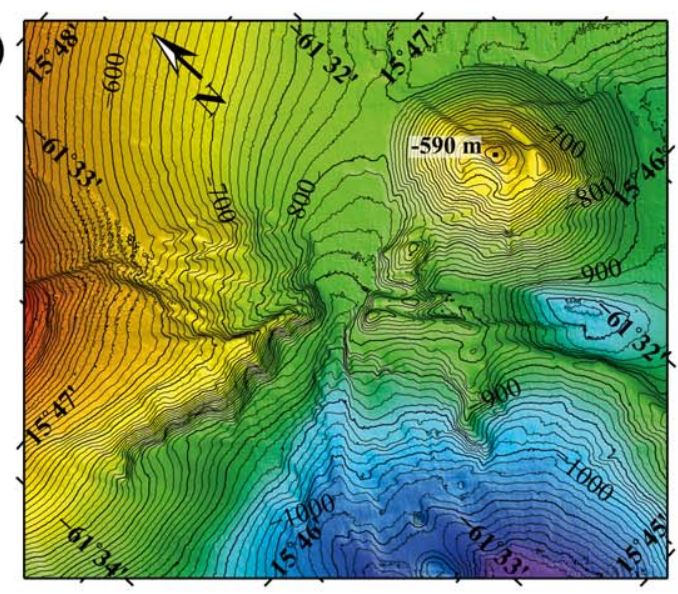

\section{Coche Volcano}

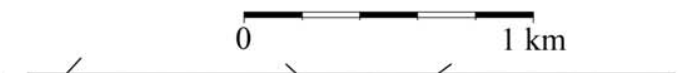

e)

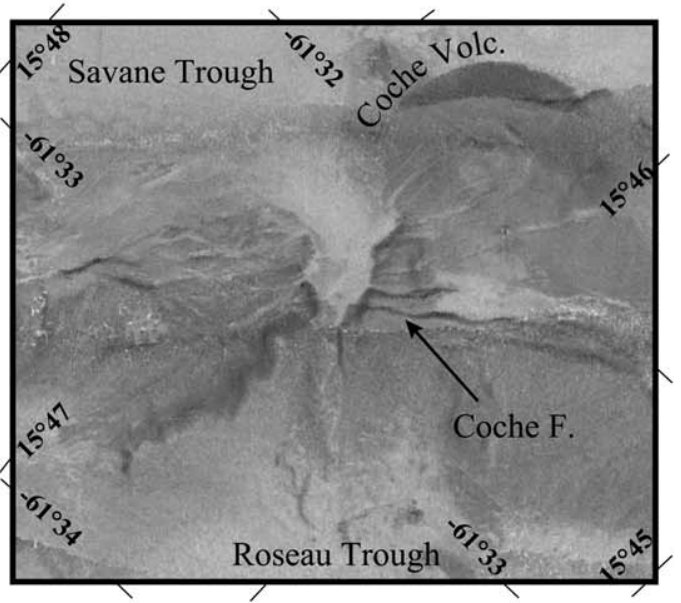

f)

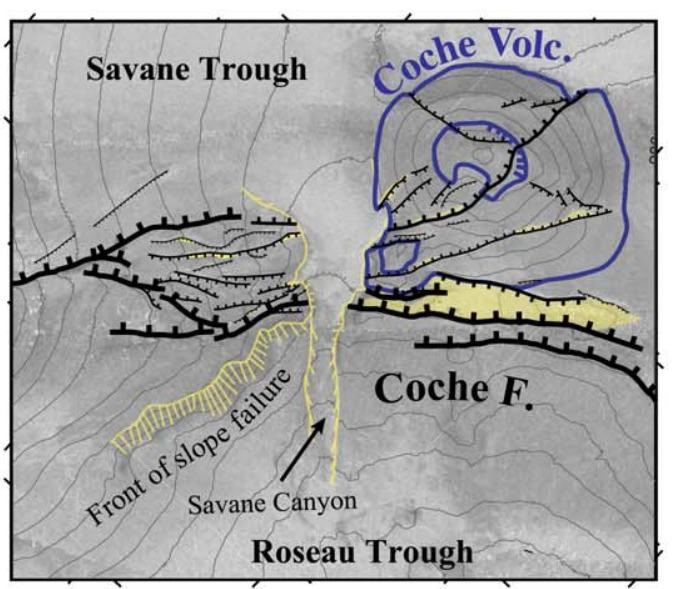

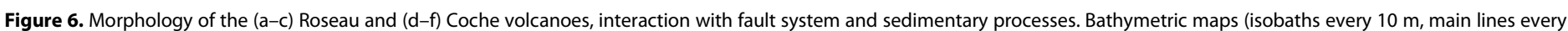

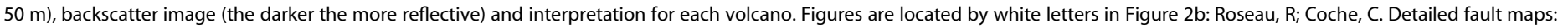
thicker traces for higher scarps. Volcanic centers in purple, basins filled by sediments in yellow, front of slope failure in yellow lines. See main text for description and interpretation.

(Figure 2 and supporting information Figures S7a and S7b), indicating that they are likely younger than Roseau volcano.

To the north, the morphology of the $300 \mathrm{~m}$ high and $1 \mathrm{~km}$ wide small Coche volcano is well preserved (supporting information Figures $6 \mathrm{~d}-6 \mathrm{f}$ ) suggesting that it is also younger than Roseau volcano. It was emplaced 


\section{QAGU Geochemistry, Geophysics, Geosystems}

a)

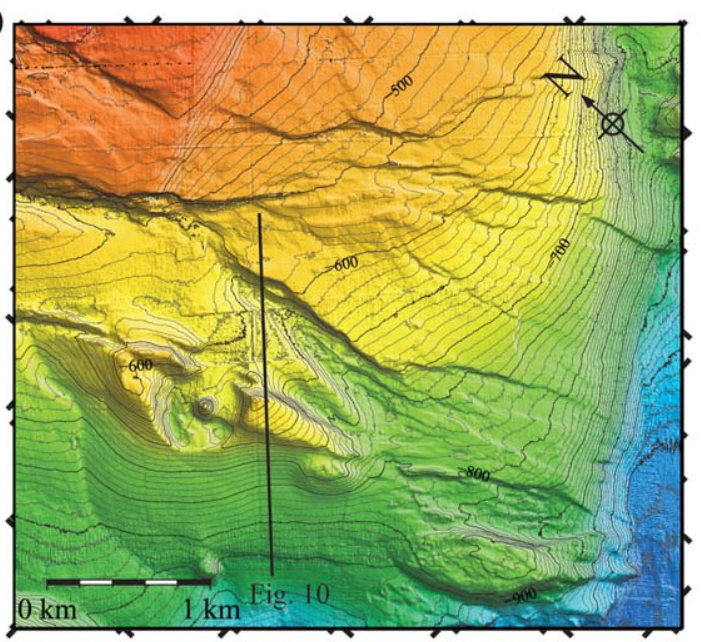

c)

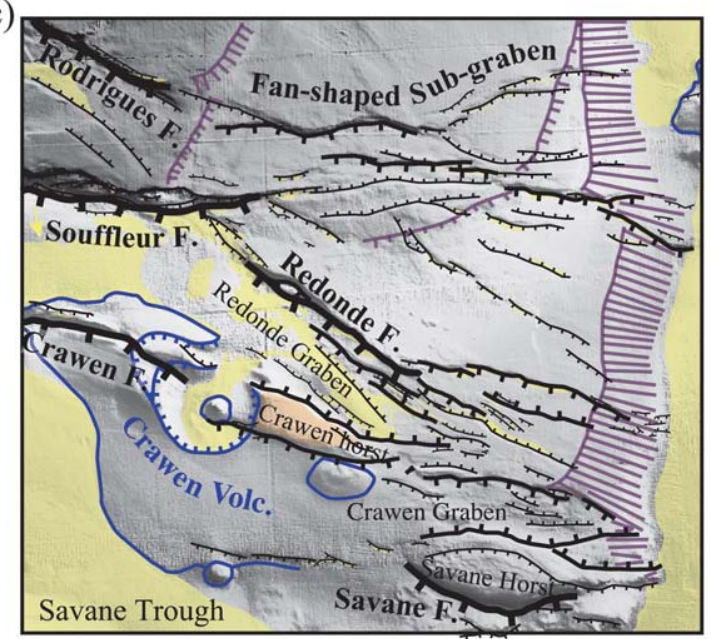

b)

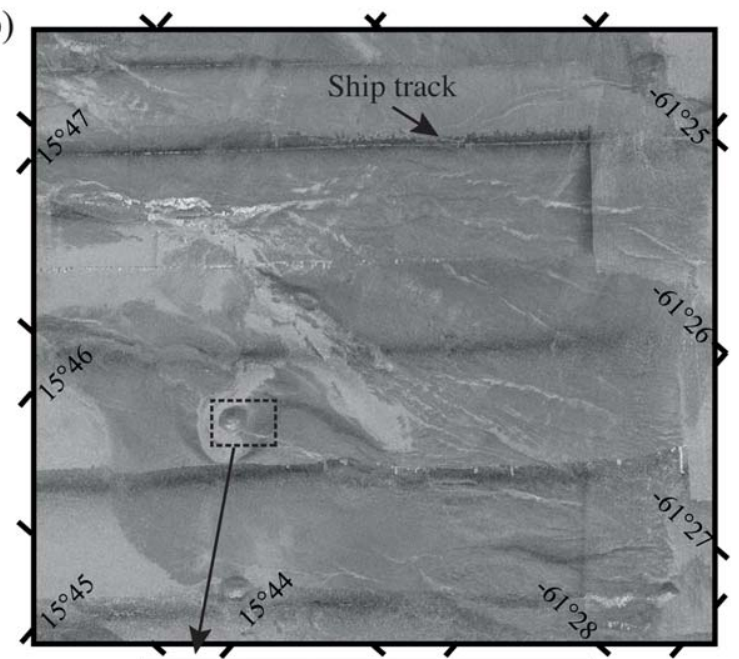

d)

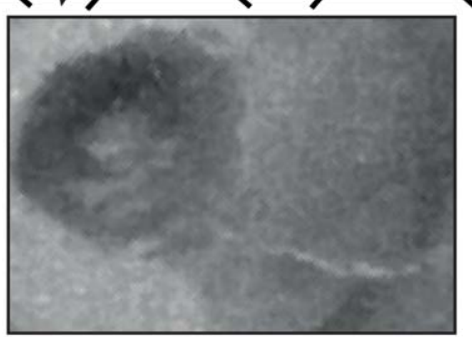

e)

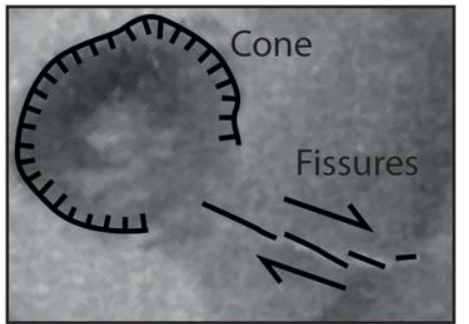

Figure 7. The southern tip of Rodrigues, Souffleur, and Redonde faults fan out southward in a damage zone and interact with the Crawen volcano. (a) Bathymetric map, isobaths every $10 \mathrm{~m}$, main lines every $50 \mathrm{~m}$. (b) Backscatter image of the area, the darker the more reflective. Fault-bounded basin appears in light grey, probably due to the presence of fine-grained sediments. (c) Detailed fault map of the area, in black, thicker traces for higher scarps. Crawen volcano in purple. Rodrigues plateau's escarpments in dark red lines. (d) Close-up view of Crawen volcano dome at the tip a left-stepping fissures and (e) map of the fissures.

within a set of open fissures and small faults (very clear in the backscatter image, Figure 6e) forming a horsetail at the termination of the northern segment of the Coche fault. A well visible horseshoe shape structure exists on the eastern flank of the volcano indicating large submarine flank collapse. Located at the horsetail tip, this structure was likely controlled by faulting.

To the east, the Crawen volcano (600 $\mathrm{m}$ deep $\sim 2 \mathrm{~km}$ long, $\sim 1 \mathrm{~km}$ wide, and $200 \mathrm{~m}$ high) presents a rather different shape. It is clearly elongated in the direction of the Crawen fault (Figures 7a-7c) and is crosscut by the fault. The top of the volcano is a very well formed $800 \mathrm{~m}$ wide and $150 \mathrm{~m}$ deep caldera. In the middle, a very well preserved $100 \mathrm{~m}$ high volcanic cone has been emplaced between two echelons of the Crawen fault at the tip of a dextral en echelon fissure parallel to the fault system (Figures $7 \mathrm{~d}$ and $7 \mathrm{e}$ ).

The 12 small Agoucha cones were emplaced in the Colibri valley (supporting information Figures S7c-S7e), between 700 and $1000 \mathrm{~m}$ bsl. The northernmost cone is the biggest. It is $220 \mathrm{~m}$ high, $1.5 \mathrm{~km}$ wide. The others are smaller, up to $800 \mathrm{~m}$ wide and $120 \mathrm{~m}$ high.

\subsection{Geometry of the Fault System at Depth and Volcanotectonic History}

We acquired several seismic profiles across the faults and volcanic system. The profile GWA005 (Figure 3) extends over the Roseau volcano. The upper part of its flanks is composed of a stratified unit, we named $\mathrm{U} 2$, characterized by a high-amplitude and low frequency seismic facies (Figures $3 \mathrm{~b}$ and $3 \mathrm{c}$ ). Further east, 

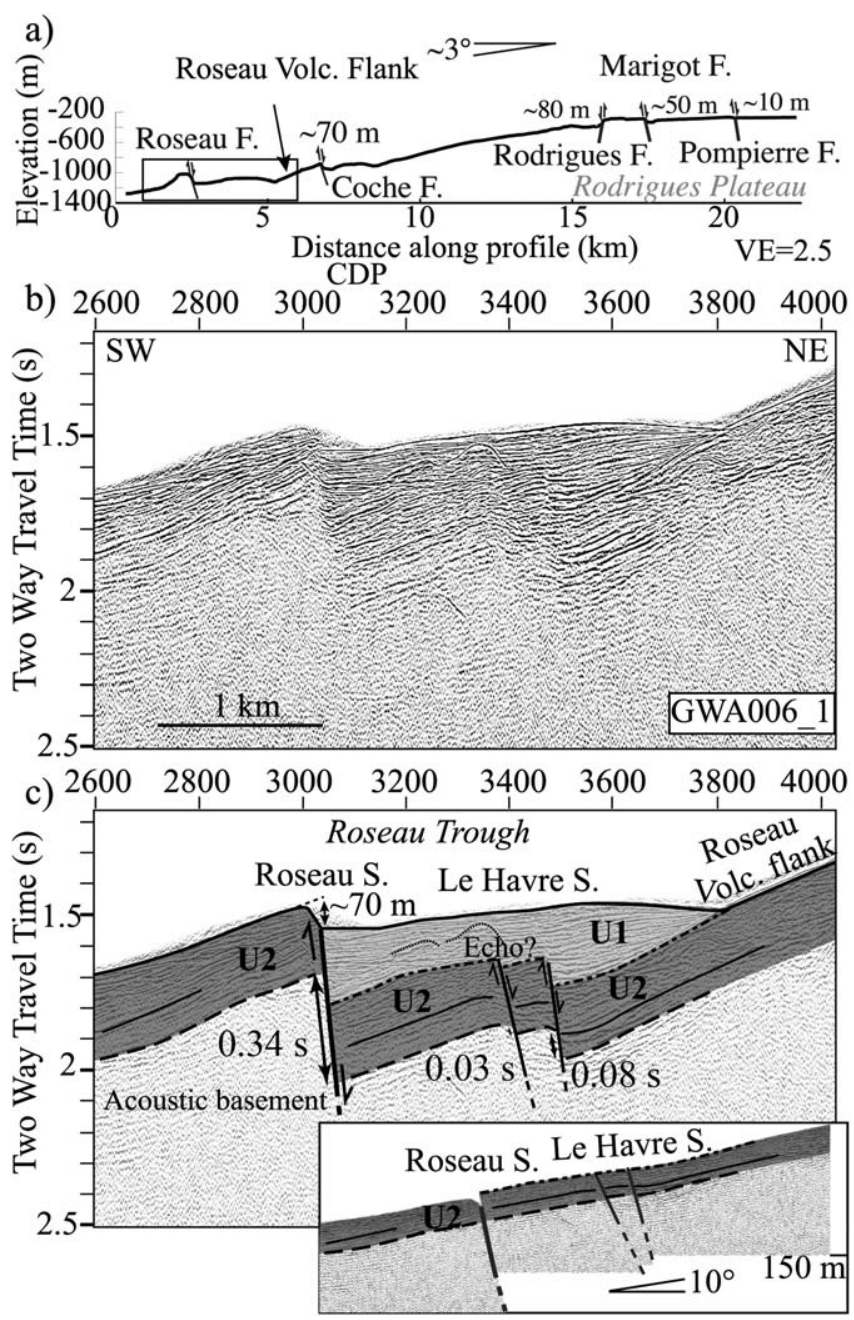

Figure 8. Interaction between Roseau fault and Roseau volcano. (a) Bathymetric profile located in Figure $2 \mathrm{~b}$ by white brackets. (b) Data and (c) interpretation of the 72 channel seismic profile GWA006_1, located in Figure $2 b$ by a white dashed line. Faults in black, with thicker traces for higher scarps. High-amplitude reflector separating the well-stratified sedimentary unit $\mathrm{U} 1$ from the unit $\mathrm{U} 2$ in bold black. See text for unit description. Le Havre segments) could reach approximately $450 \mathrm{~m}$ (using a velocity of $2000 \mathrm{~m} / \mathrm{s}$ for a total offset of $0.34+0.08+0.03=0.45 \mathrm{~s}$ TWTT, Figure $8 \mathrm{c}$ ). Moreover, it was also possible to estimate horizontal widening of about $150 \mathrm{~m}$ since U2 deposition.

The Rodrigues plateau is characterized by a well-stratified thin sedimentary unit P1, composed of parallel high-amplitude thin reflectors. Its thickness varies on the plateau, being at most 100-150 m thick $(0.15 \mathrm{~s}$ TWTT, Figures 3 and 9). It is highly reflective in the backscatter image (supporting information Figure S2c). This unit overlies a more transparent, locally high basement (P2) that makes up the Rodrigues plateau [Bouysse and Gennoc, 1983]. All faults offset unit P2 by tens to hundreds of meters (Figures 3 and 9). Farther south on profile GWA003 that crosscuts the fan-shaped subgraben (Figure 9), the faults are more numerous and have smaller scarps. All faults reach the surface, attesting for recent activity. Moreover, the seafloor is offset by the same quantity as unit $\mathrm{P} 1$ and $\mathrm{P} 2$, and this implies that the faults postdate the deposition of $\mathrm{P} 1$.

The seismic profile GWA004 crosscuts the Crawen and Redonde fault system south of the Crawen caldera, perpendicular to the Crawen horst (Figure 10). Units P1 and P2 can be identified at depth, below the volcanic deposits (characterized by high-amplitude and high-frequency seismic facies). The Crawen volcano postdates the deposition of units $\mathrm{P} 1$ and $\mathrm{P} 2$, and the formation of its caldera probably disrupted the uppermost 


\section{QAGU Geochemistry, Geophysics, Geosystems}

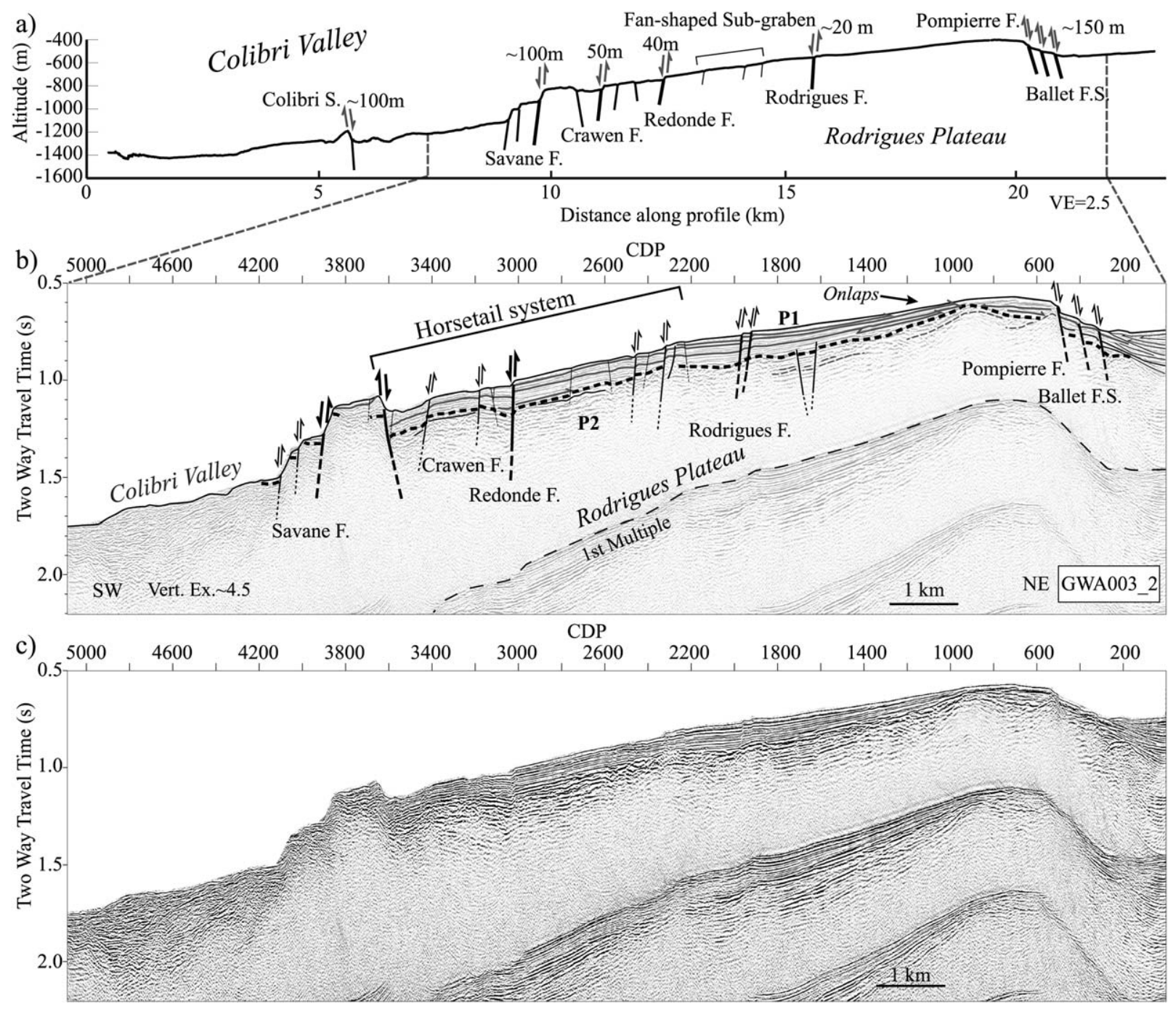

Figure 9. Seismic reflection profile across the Rodrigues plateau. (a) Bathymetric profile located in Figure $2 b$ by white brackets. (b) Data and (c) interpretation of the 72 channel seismic profile GWA003, located in Figure $2 \mathrm{~b}$ by a white dashed line. Faults in black, with thicker traces for higher scarps. See text for unit description.

unit P1. Volcanic activity spreads material around that form wedges on both sides of the horst. To the east, the deposit is about $100 \mathrm{~m}$ thick. It is crosscut by the faults of the Redonde graben but its distal part is partially buried under more recent sediments. A first order reconstruction (Figure 10d) suggests that this wedge predates the activity of the Redonde graben faults. To the west, the wedge is much thicker, reaching up to $230 \mathrm{~m}$ height at the base of the Crawen fault, suggesting syntectonic deposition. It contains 2 units displaying chaotic seismic facies, typical of slope failure deposits. The lower and thicker chaotic unit seems to have partially eroded the top of P1 near the Crawen fault.

Overall, considering these relations, we can summarize the relative chronology of deposition and faulting. To the east, the fault system disrupts the Rodrigues plateau made of two seismic units (P1 and P2) that have been deposited before faulting. The faults disrupt and deform several volcanic complexes, some having been emplaced across the Rodrigues plateau (e.g., Crawen). The Roseau volcano is probably the oldest edifice because it was emplaced before fault activity. The other and younger volcanic complexes (Colibri, Carrata, Coche, and Crawen) are only cut by few faults with small offsets suggesting that they emplaced during fault activity, as also inferred by morphological analyses (sections 3 and 4). More recent sediments associated with volcanic activity or mass-wasting processes were deposited syntectonically within faultbounded depression and cut by the youngest faults (Crawen and Redonde graben). Independently, the deposition of the Les Saintes reef plateau predates the activity of the northern segments of the Pompierre and Marigot faults [Leclerc et al., 2014]. 
a) Roseau F. Savane Trough Souffleur F. Marigot F.

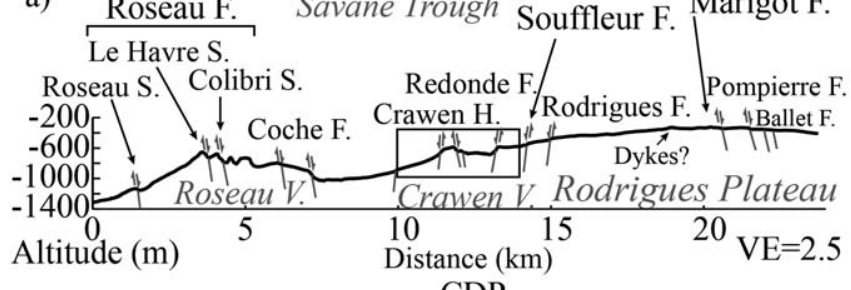
CDP

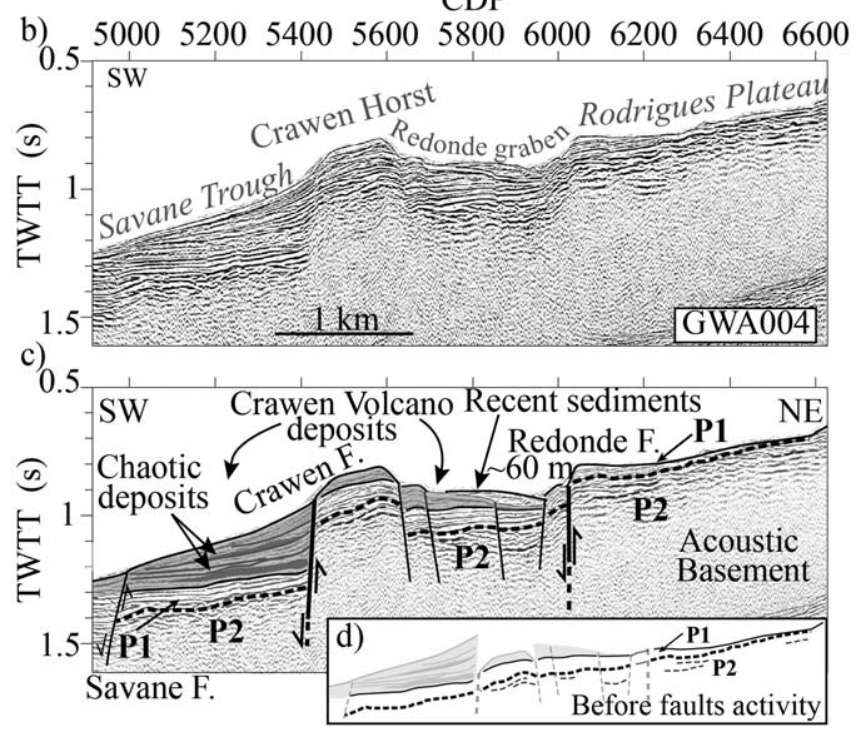

Figure 10. Interaction between faults and Crawen volcano deposits. (a) Bathymetric profile, located in Figure 2a by white brackets. (b) Data and (c) interpretation of the 72 channel seismic profile GWA004, located in Figure $2 \mathrm{~b}$ by a white dashed line. (d) Reconstruction of the profile before faulting. Using a uniform wave propagation velocity of $1800 \mathrm{~m} / \mathrm{s}$ in the sediments [Shalev et al., 2010], the faults would dip by about $65^{\circ}-80^{\circ}$ northeastward. during sea level variations, and finally earthquake induced ground shaking [Schlager et al., 1984]. In Les Saintes, the post-LGM reef was established on the Les Saintes platform following the preexisting amphitheater-shaped morphology [Leclerc et al., 2014] attesting that the canyon heads are long-lived structures. Inside the largest ( $2 \mathrm{~km}$ ) amphitheater-shaped structure S5, several arcuate slump scars are present and record retrogressive erosion within the canyon's head up to a depth of $200 \mathrm{~m}$ (Figure 12).

The turbiditic system is strongly perturbed by faulting (Figure 12). At about -400 to $-600 \mathrm{~m}$, the Canyon segment, constituting the northern extent of the Roseau fault, has never been identified before this study. It crosscuts the platform's western slope, driving subsidence of the upper slope and uplift of the lower slope (Figure 12). Whereas the head of canyons S1, S5-S7 are connected to their $\sim 1 \mathrm{~km}$ wide, up to $200 \mathrm{~m}$ deep downstream channel, the head of canyons S2-S4 are disconnected from the rest of the turbiditic system by the fault. Sediments resulting from slope failures at canyon heads probably accumulate at the base of the scarp that now acts as a dam. Downstream, and beyond the fault trace, the turbiditic system is composed of numerous thin gullies that erode the uplifting fault footwall, rather than a sole channel. Bathymetric profile $\mathrm{c} 1$ (Figure 12d), perpendicular to the turbiditic system, show the two sets of canyons: the largest canyons to the north, connected to their amphitheater-shaped head, and the much smaller gullies to the south, disconnected from the upper part of the system and eroding only the uplifting fault footwall. The latter set is composed of two subsets that may be of different generations: 50-100 m wide, 100-150 m deep canyons are overprinted by smaller ones ( $20 \mathrm{~m}$ wide and $50 \mathrm{~m}$ deep, Figure $12 \mathrm{c}$, and bathymetric profile $12 \mathrm{~d}$ ). Bathymetric profiles, obtained perpendicularly to the fault, show that the fault scarp is up to $50 \mathrm{~m}$ high on interfluves, i.e., between two canyons (profile c2, Figure 12e), and has no topographic expression inside the canyons (for instance in S3, profile c3, Figure 12e). We calculate that faulting increases the slope of the Saintes plateau by $\sim 3^{\circ}$ due to footwall flexure (Figure 12e). This is probably enough to facilitate the 


\section{QAGU Geochemistry, Geophysics, Geosystems}
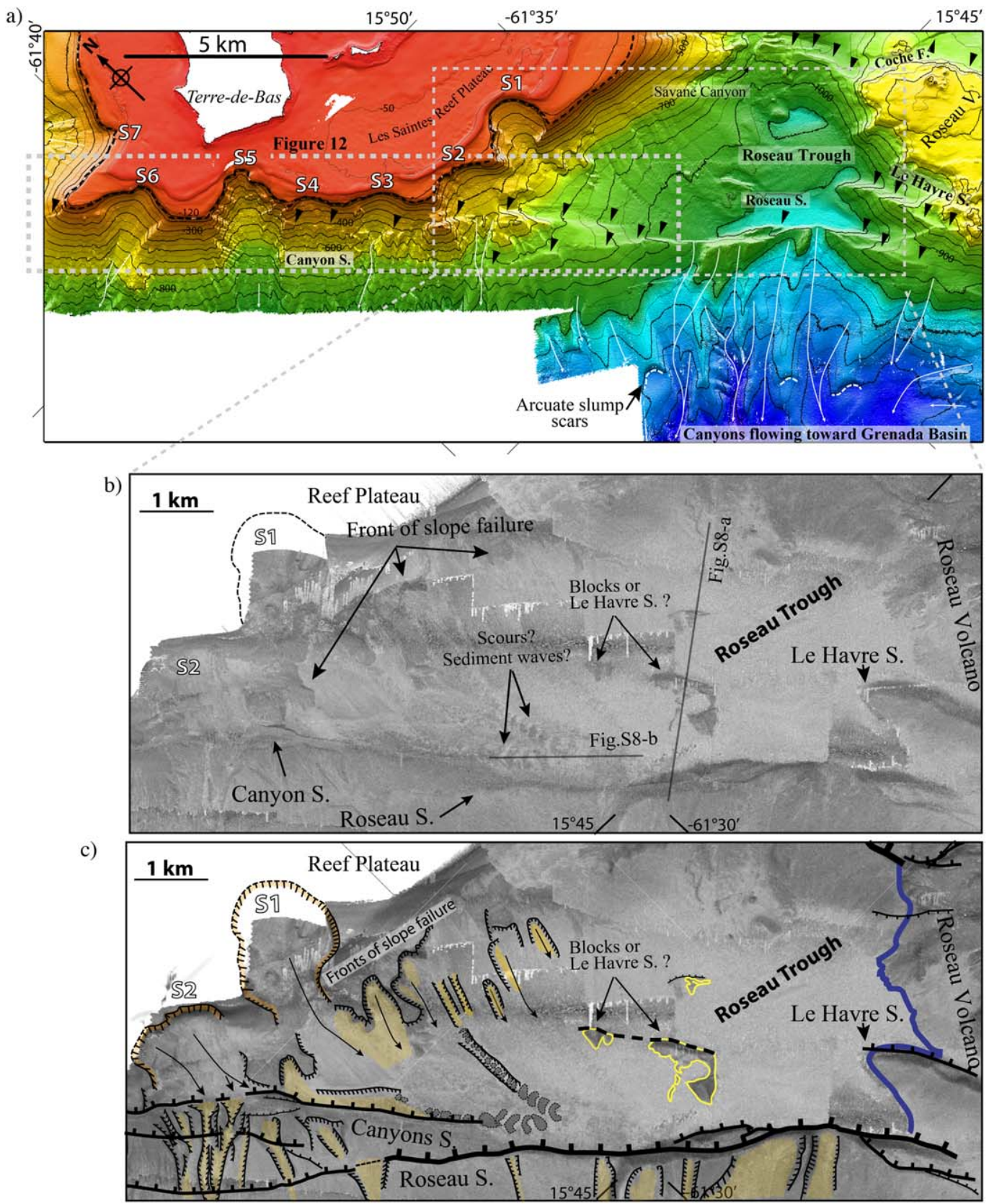

Figure 11. Interaction between faulting and the turbidity system. (a) Bathymetric map of the area. Several canyon heads (numbered S1S7) dissect the plateau. Canyons are flowing southwestward (the bed of the bigger canyons are represented by white arrows), toward the Grenada Basin. Arcuate slump scars (in white dashed lines) indicate that canyons are formed by retrogressive erosion. Isobaths every $50 \mathrm{~m}$, major ones every $100 \mathrm{~m}$. (b) Backscatter images of the Roseau trough and (c) morphological interpretation from backscatter image draped on 3-D bathymetry.

formation of gullies, through sediment failure. Within the gullies, the scarp is totally eroded. Erosion rates must then equal or surpass the footwall uplift rate.

Farther south, the Roseau segment scarp is up to $200 \mathrm{~m}$ high (Figure 11). Dipping to the east, it acts as a dam retaining the sediment coming from the larger amphitheater-shaped canyon heads S1 and S2 in the Roseau Trough. In this trough, the slope of the plateau is entailed by channels in which we observed clear hundred meter wide sedimentary structures characterized by strong contrasts of reflectivity in the backscatter image (black and white alternations), hyperbolic signal in chirp subbottom profiles (Figure S8a), and smaller undulations in the bathymetry (probably less than few meters high) that could be either scours or 


\section{QAGU Geochemistry, Geophysics, Geosystems}

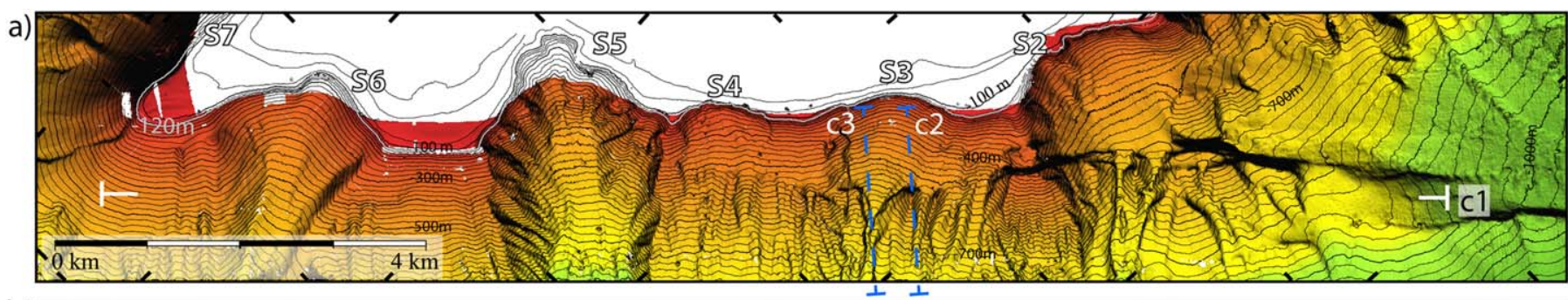

b)
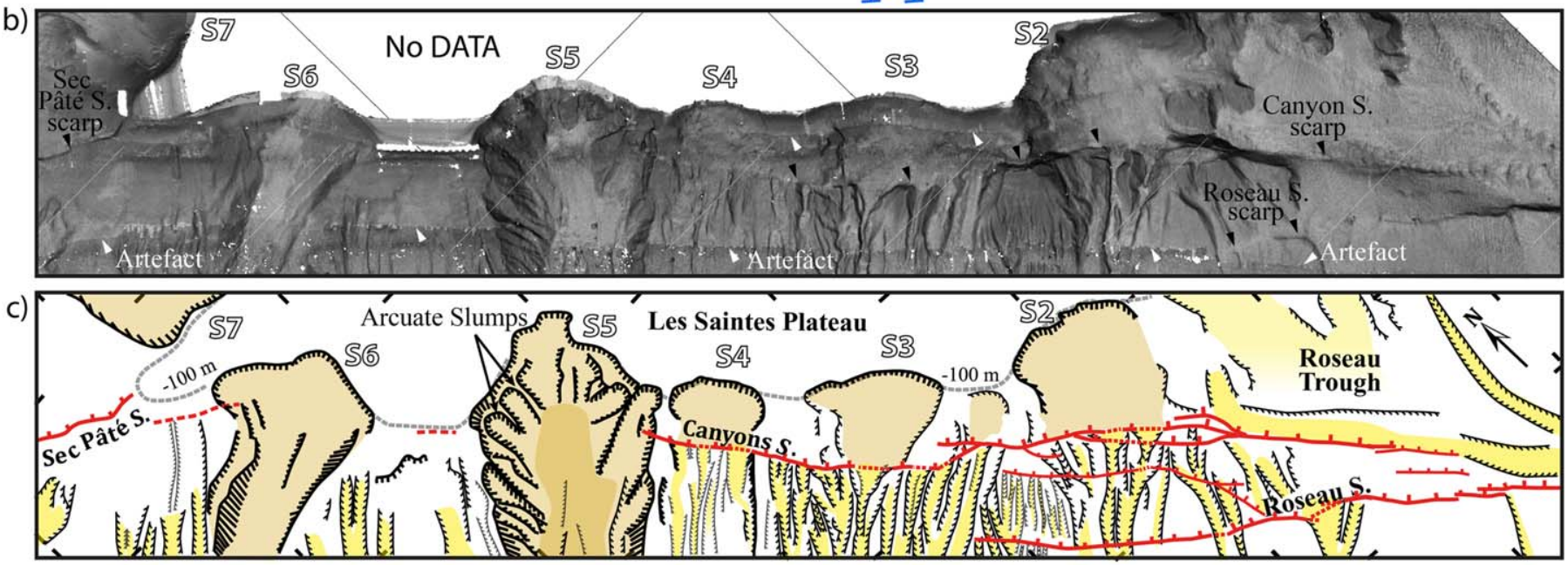

d)

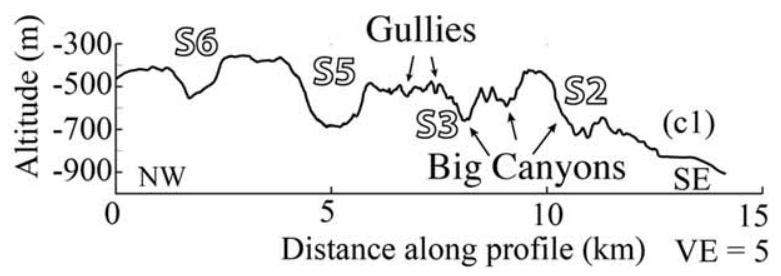

e)

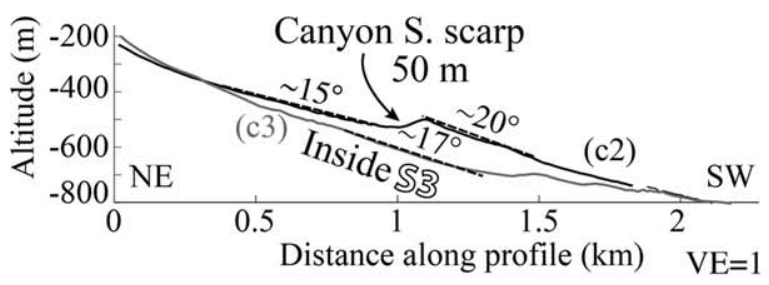

Figure 12. Interaction between faulting and development of canyons. (a) Bathymetric map, isobaths every $20 \mathrm{~m}$, major ones very $100 \mathrm{~m}$, located in Figure $11 \mathrm{a}$. (b) Backscatter data draped on 3-D bathymetry (see supporting information Figure S2c for backscatter image only). (c) Interpretation: the fault trace (in red) is affected by the main canyons (in orange) and

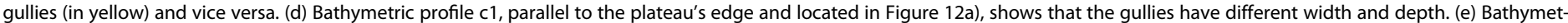

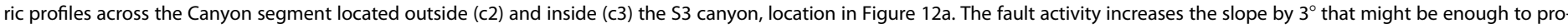
duce sediment failure, development of a gully or canyon to retrieve a smaller slope.

sediment waves, resulting from turbidity currents [e.g., Fildani et al., 2006; Wynn et al., 2002]. Two $500 \mathrm{~m}$ wide and $50 \mathrm{~m}$ high highly reflective reliefs lie in the Roseau trough (Figure 11b). They could be either remains of a fault scarp buried in the trough or large transported blocks. The chirp and seismic profiles (supporting information Figure S8b and Figure 8) are characterized by hyperbolas that could be associated with coarse deposits that can typify sudden sediment inputs from slope failure.

Conversely, the Roseau fault scarp is affected by the turbidity system. In the canyon head S5, the fault scarp disappears either because the fault segment terminates in this location or because it cannot be preserved due to recent mass-wasting events.

We discussed earlier the small-scale morphological feature of the central part of the Roseau fault scarp (section 3.3 and Figure 4). At larger scale, the height of the Roseau segment scarp strongly varies along strike ranging between 10 and $200 \mathrm{~m}$ high in a few hundreds of meters (Figure 13). It is unusual to have such strong variations in the height of a scarp along only one segment of a fault, in the middle of the segment (while extremis are tapering) and at that scale [i.e., Manighetti et al., 2009]. It has been shown that the cumulative slip of normal faults usually follows an elliptical or triangular-shaped distribution [Manighetti et al., 2001]. In Les Saintes, the shape of the scarp is in fact due to erosion. Indeed, the Roseau fault footwall is incised perpendicular to the fault strike, by kilometer-wide canyons flowing southwestward, toward the Grenada Basin (Figures 1 and 13). These canyons also develop through retrogressive erosion, several 


\section{QAGU Geochemistry, Geophysics, Geosystems}

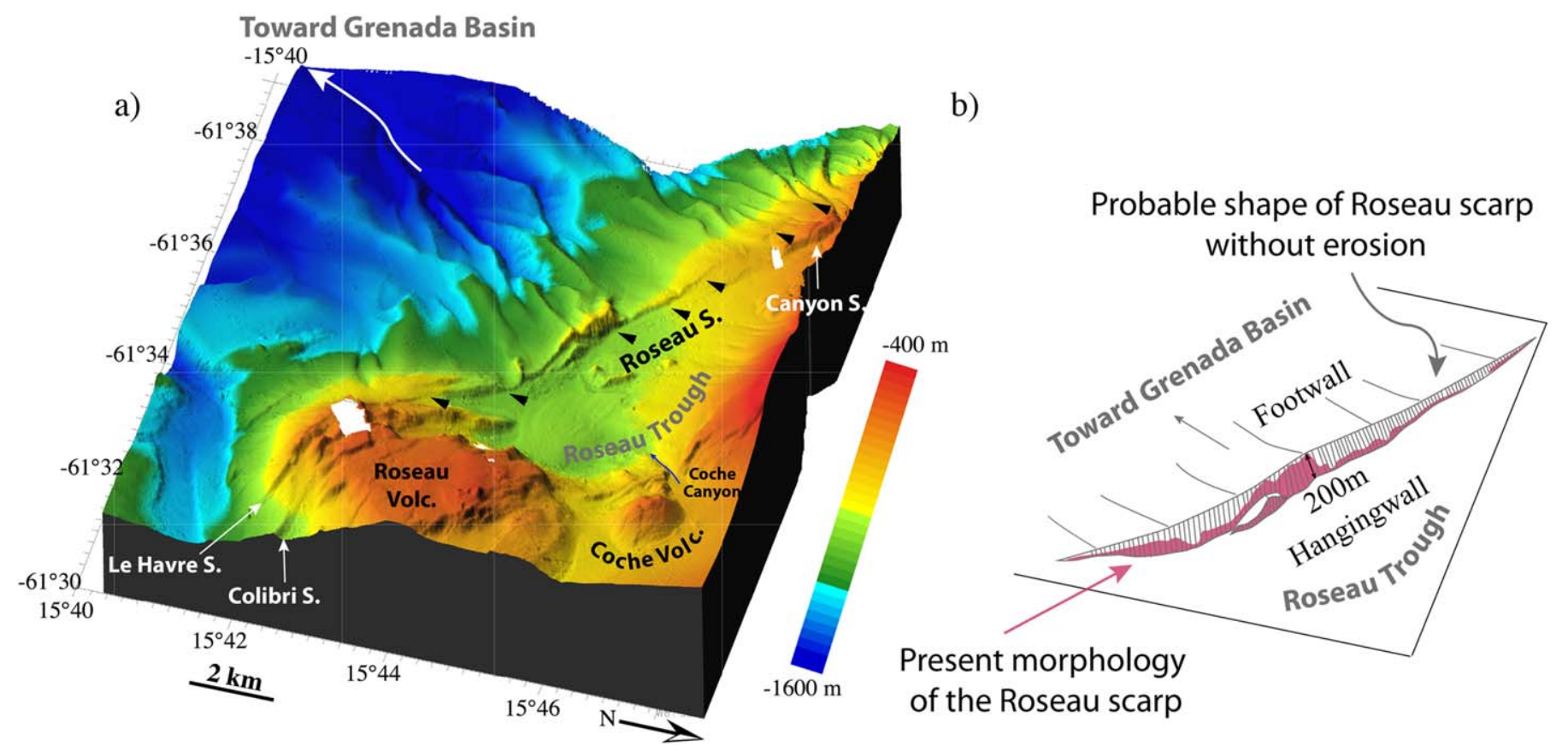

Figure 13. The Roseau fault footwall is eroded by retrogressive erosion, which induces high fluctuations in its scarp height when canyons reached the scarp edge. (a) 3-D view of the area. b) Morphology of the Roseau scarp: present morphology in pink compared to a probable scarp shape in grey that would not have suffered from erosion.

arcuate slump scars being observed at the top of canyons, which have not reach the fault scarp yet (Figure 11a). Therefore, while the scarp is growing at the time of an earthquake, it is eroded at some places via turbidity currents that can be themselves triggered by earthquake-related ground shaking.

Another good example of scarp erosion can be documented along the Coche fault system (Figure $6 \mathrm{~d}$ ). The small fault scarps forming a horsetail structure are not preserved where the seafloor is excavated by the small $50 \mathrm{~m}$ deep, $200 \mathrm{~m}$ wide Savane canyon flowing toward the Roseau trough. The canyon head is an area of low reflectivity suggesting sediments ponding on the fault down-dropping hanging wall.

At the base of the Les Saintes reef platform, the eastern part of the Rodrigues plateau is being covered by sediments, probably coming from the surrounding carbonate systems (from Grande-Terre, Les Saintes platform, etc.). Sediments are forming a few meter high and less than a hundred meter-wide sediment waves between 220 and $310 \mathrm{~m}$ bsl (Figure 14), whose strike varies from east-west to almost north-south, toward the south. As the waves are always elongated in the direction perpendicular to the slope, they most probably are created by unconfined turbidity currents [Wynn et al., 2000; Wynn and Stow, 2002]. They are crosscut by the Pompierre fault system, whose scarp at this place only measures 2-5 m (Figure 14c). This indicates that these sediment waves have, at a certain period of time, covered the area, erasing the fault scarp that measures several tens of meters southward.

South of this area, evidence of sediment waves are found in bathymetry and backscatter images at the mouth of the Colibri valley (Figure 2, supporting information Figures S2 and S7c-S7e). Accumulation of sediments there may have buried the small scarps at the tip of the easternmost east dipping faults. Sediment waves are aligned obliquely to the seafloor slope, indicating that they result from bottom currents [Wynn and Stow, 2002]. This current contours the easternmost cone of the Agoucha volcanic complex, excavating sediments at its flanks that are then distributed farther away.

Overall, these examples illustrate the competition between active faulting, volcanoes, erosion and deposition of sediments offshore.

Based on the overall morphology of the area, we can make some hypothesis on the age of some of the sedimentary processes that carved or covered the scarps, and therefore on the age of the scarps.

In carbonate (Bahamas and Nicaragua Rise) and mixed carbonate-siliciclastic (Gulf of Papua) environments, Jorry et al. [2010] reviewed the timing of calciturbidites deposition and demonstrated that turbiditic 

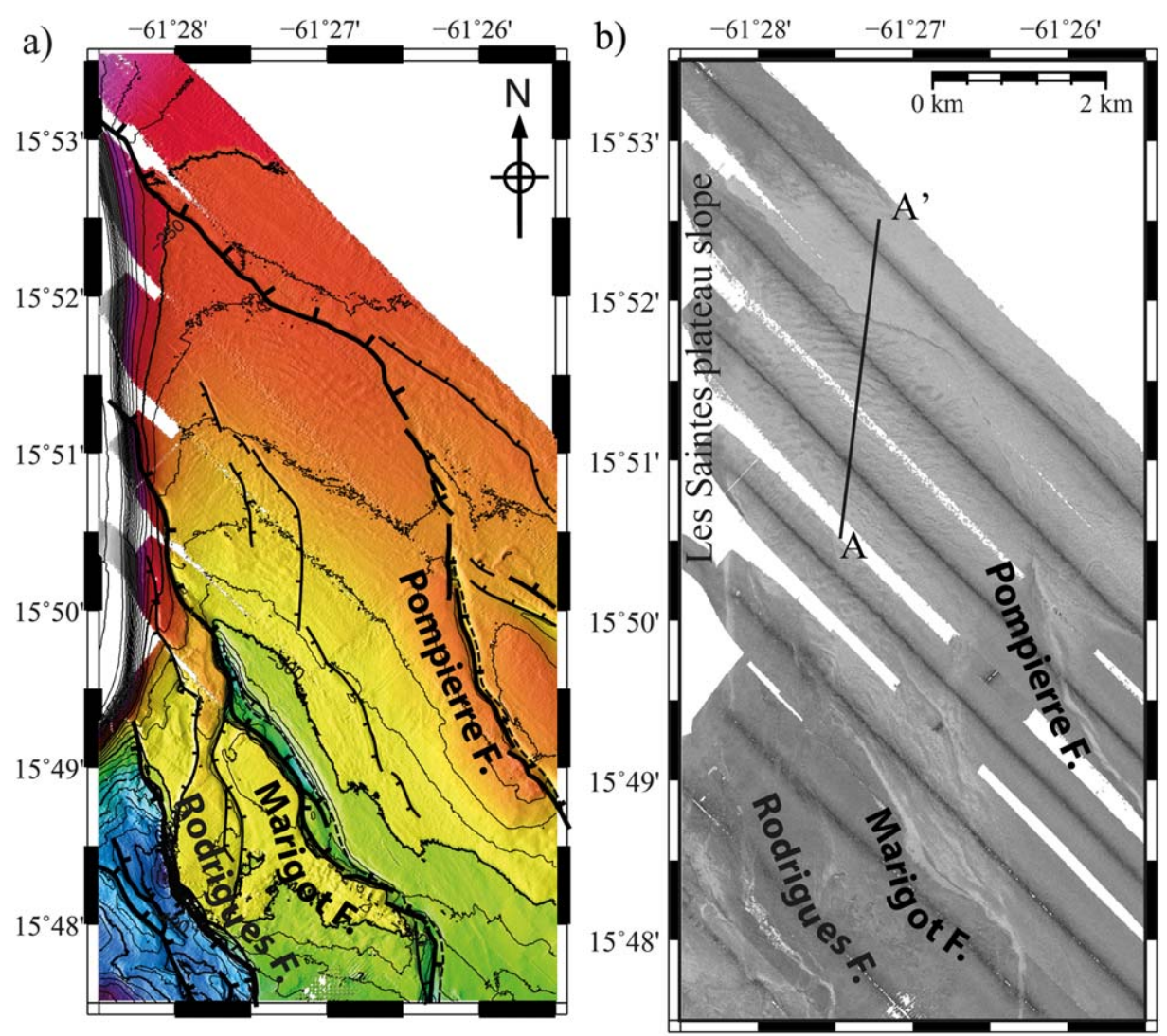

c)

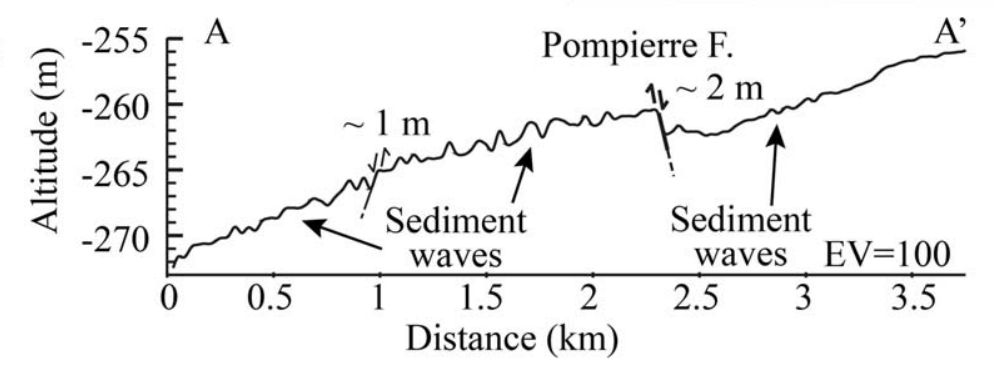

Figure 14. Marigot and Pompierre faults are crosscutting sediment waves at the base of Les Saintes plateau: (a) bathymetry, (b) backscatter image, location in Figure $2 \mathrm{~b}$. (c) Bathymetry profile $A A^{\prime}$. The sediment waves are $\sim 1 \mathrm{~m}$ high and tens meters wide and offset by $2-5 \mathrm{~m}$.

deposits accumulate in proximal basins mostly during periods of platform flooding (called "reflooding window") $^{\prime \prime}$ and subsequent highstands, when neritic production, and therefore sediment supply, is high (recently confirmed by Puga-Bernabéu et al. [2013] along the Great Barrier Reef). The canyons are consequently more active during these reflooding episodes.

In Les Saintes, the open carbonate platform lies mainly between 110 to $40 \mathrm{~m}$ bsl. It was consequently completely flooded after the Last Glacial Maximum (LGM, 20 ka ago), when the sea level rose from $120 \mathrm{~m}$ bsl to its current level. While the sea was rising, the post-LGM reef was able to grow on the platform, neritic production being therefore high at that time. The post-LGM reef gave up around 10 ka ago [Leclerc et al., 2014], leading to the drowning of the platform at $40 \mathrm{~m}$ bsl. Since then, the neritic production must have been lower and concentrated around the islands.

In Les Saintes, turbiditic flows were therefore mainly active since the LGM until the platform's demise 10 ka ago. The sediment waves derived from unconfined turbidites and located along the south-eastern base of the platform (Figure 14) would have consequently formed during the same period, implying that the 2-5 m high Pompierre fault scarp is about $10 \mathrm{ka}$. In parallel, turbidity flows channeled in the canyons along the western slope of the platform (Figure 12) must have erased the Canyon segment scarp between interfluves since the LGM. 
By making an extreme hypothesis, we can imagine that during each shelf reflooding period, the fault scarp can be totally eroded due to intense erosion processes and canyon activities. In this case, the remnant $50 \mathrm{~m}$ high fault scarp, visible nowadays at interfluves, would have grown since the penultimate reflooding window (preceding the last interglacial highstand) for at least $130 \mathrm{ka}$.

\section{Discussion}

\subsection{Fault System Geometry}

We have documented at several scales, numerous active faults in Les Saintes channel between Basse-Terre and Dominica. The largest Roseau fault was previously identified as responsible for the Mw 6.3 earthquake of 21 November 2004 [Bazin et al., 2010; Feuillet et al., 2011]. Its fine geometry was however not well constrained because previous data were of much lower resolution [Feuillet et al., 2010]. Its extension along the western slope of the Les Saintes plateau was also unknown and we showed that the fault is longer than previously inferred. This result implies that this fault could generate $\mathrm{Mw} 7$ earthquakes in the future [Wells and Coppersmith, 1994] if a rupture can break the whole length of the fault, which is not unrealistic as a Mw 7.4 earthquake occurred in 1974 along a crustal fault of the same system near Antigua [McCann et al., 1982]. The 2004 earthquake occurred along the central part of Roseau fault system in the Roseau trough [Feuillet et al., 2011]. The slip model implies that the portion of the fault, located along the western slope of the plateau, just below the Saintes islands remains unbroken (Figure 2b) [Feuillet et al., 2011]. Located at the tip of the rupture, this segment was certainly brought closer to failure and remains a serious threat for the population. Numerous small aftershocks have however occurred in this area, maybe contributing to a partial release of the stress. For instance, in April 2008, a swarm consisted of about 1200 events of magnitude up to 3.9 (http://www.ipgp.fr/pages/0303040901.php).

As documented by Feuillet et al. [2010], Les Saintes faults form an asymmetric arc-parallel graben. They arranged in right-stepping echelons along a $\mathrm{N} 140^{\circ} \mathrm{E} \pm 10^{\circ}$ and in dextral echelons along a $\sim \mathrm{N} 110^{\circ} \mathrm{E}$ direction, in agreement with an extension direction between $\mathrm{N} 30^{\circ} \mathrm{E} \pm 10^{\circ}$ and $\mathrm{N} 60^{\circ} \mathrm{E} \pm 20^{\circ}$, compatible with the focal mechanism of the 21 November 2004 mainshock. Our higher resolution data did not reveal any evidence of lateral (strike-slip) cumulative offset of small geomorphic markers. However, the Roseau volcano is elongated in a $\sim \mathrm{N} 25^{\circ} \mathrm{E}$ direction, compatible with sinistral shear between the Roseau and Coche fault segments.

We showed that the eastern system, which crosscuts the Rodrigues plateau terminates in a horsetail manner as observed elsewhere at propagating fault tips [Perrin et al., 2016]. No surface trace of active faulting is evident southward beyond the Rodrigues plateau, in the Colibri Valley, where the fault system seems to terminate.

\subsection{About the Small-Scale Morphology of the Faults}

The high-resolution images we obtained along the fault scarps by the side-scan sonar are uncommon data, and show that the submarine escarpments are better preserved than onshore escarpments that may be continuously erased by weathering and covered by vegetation. These images combined with the bathymetry data, document the small-scale complexities of the scarps, which probably originate from failure processes in the subsurface. The morphology of the Souffleur fault scarp seems strikingly similar to a normal fault scarp formed by hybrid failure (tensile and shear) in analogical small-scale models [Kettermann and Urai, 2015]. It differs from the Roseau scarp's morphology that is more compatible with shear failure. This may reflect differences in properties of faulted geological units or differences in the weight of the column of water above the faults (Roseau fault is deeper than Souffleur fault). The water column height or weight effect is certainly comparable to that of the overburden thickness explored in Kettermann and Urai [2015]'s experiments: an increase of the overburden thickness leads to a failure mode closer to the shear failure end member than to the tensile one. Consequently, for a given lithology, the water depth at which the fault is lying could determine the way a seismic rupture propagates toward the seafloor, affecting both the dynamic displacement and the finite displacement pattern (depending on fault dip, complexity of the fault, etc.) at the seafloor. If so, determining if there is a water depth threshold at which the failure changes from tensile to hybrid and then to shear mode would be of great importance because the dynamic and finite displacements at the seafloor during an earthquake modulate tsunami generation and propagation [e.g., Tanioka and Satake, 1996; Ohmachi et al., 2001]. On the Rodrigues plateau, the morphology of all the scarps seems 
to indicate that fault's failure mode change from hybrid to shear at around $600-700 \mathrm{~m}$ bsl. This corresponds to a hydrostatic pressure of $\sim 6-7 \mathrm{MPa}$ at this depth, equivalent to an overburden thickness of rocks of 200$250 \mathrm{~m}$, for a density of rocks of 2.8 for instance. Further work is needed to investigate the influence of water depth on the failure mode of faults.

Along the cumulative scarps, we also observed alternation of high and low reflective lines on the side-scan sonar images. Using the data set presented in this paper, we have proposed in the previous section 3.3 that these alternations coincide to steps in the bathymetry that may be explained by geological strata but also correspond to free faces formed during the last earthquakes on faults. Along the Roseau fault, microbathymetry data were recently gathered [Escartín et al., 2016] and confirm the stair case morphology of the cumulative scarp with steps, decimeters to meters high, mostly due to layered volcanic deposits. These new data, combined with photomosaic data as well as direct observations, also enabled to image the surface rupture of the 21 November 2004 Les Saintes earthquake at the base of the cumulative scarp [Escartín et al., 2016]. Future work will focus on understanding the cumulative scarp's growth and degradation at the time scale of the seismic cycle.

\subsection{Interaction Between Faulting and Volcanism}

We identified several submarine volcanic features in the area. The best-preserved ones (Colibri, Yanti, and Agoucha) are probably the youngest ones. They emplaced southward at the tip of the graben, where the deformation is much more distributed typifying a damage zone [Kim et al., 2004]. Manighetti et al. [2004] have modeled the pattern of strain at the end of such complex system (triangular damage zones composed of cracks at an angle to the main fault, i.e., horsetail style). They show that the strain increases at the tip of the damage zone on tension cracks oriented parallel to the main fault and perpendicularly to the minimum compressive stress $\sigma 3$, in an area as large as the fault system. The Agoucha cones and the Colibri volcano may have emplaced along such fissures, at the southern tip of the fault system. The horsetail structure we identified at the tip of the eastern system is composed of small faults but also numerous fissures opened by few meters and very clear in our backscatter images because they are filled by less reflective sediments. This is compatible with tensile failure at the fault tip and may favor intrusion of volcanic vents at this place. In addition, the Agoucha cones emplacement perpendicularly to the arc could be in part related to process zone heating in this complex damage zone [Devès et al., 2014]. Other volcanic complexes are emplaced coevally with faulting, for example the Crawen volcano likely intruded along the Crawen fault, but before the initiation of the Redonde graben faults. Some vents (Carrata) align along fissures parallel to faults accommodating the extension within the graben. Overall, the faults have controlled the emplacement of the more recent volcanic complexes as well as probably their eruptive history, for example by facilitating their flank collapses in certain directions.

In Les Saintes, faulting and volcanism interact with each other: (1) the fault system initiated along the volcanic arc; (2) the faults subsequently control the formation of recent edifices. All the volcanoes are crosscut by fault segments or located at their tip. Such a colocation is not always observed along island arcs where faulting due to slip partitioning and volcanism are both present. In Sumatra for instance, Sieh and Natawidjaja [2000] show that most of the volcanic edifices are not located on the Sumatran fault segments (only $20 \%$ are within $2 \mathrm{~km}$ of the fault). They question the existence and influence of an upper plate weak zone created by volcanism that would control the location of the fault along the arc. Instead, they favor the hypothesis of McCaffrey et al. [2000] who propose that the location of the fault is controlled by the distribution of high basal shear stress along the megathrust. In the Lesser Antilles, the location of the fault system could be also linked to the megathrust rheological properties but clearly controls the subsequent volcanic activity along the arc.

\subsection{Preliminary Estimation of Fault Slip Rates}

We have no absolute datings of markers offset by the faults and we cannot precisely estimate the slip rate of the faults. However, based on our morphotectonic and geological analysis of the Les Saintes volcanotectonic system, we can gain some information useful to this goal. The oldest volcanic complex of the system (Roseau) predates the initiation of faulting. The age of this volcano would thus be critical to estimate Roseau fault slip rate but is unknown. The age of adjacent volcanoes on land can however help to place bounds on the age of initiation of the offshore volcanism. In Dominica, Mornes aux Diables and West Cabrit dacitic domes build up during Older Pleistocene, around 1.8 Ma [Lindsay et al., 2005, and references therein]. In Les 
Saintes, Zami et al. [2014] showed that the volcanic activity lasted between $\sim 3$ and 2 Ma in Terre-de-Haut and resumed in Terre-de-Bas during a short period of time, around $0.9 \mathrm{Ma}$. The Roseau volcano is then probably younger than $3 \mathrm{Ma}$, implying a minimum slip rate of the order of $0.15 \mathrm{~mm} / \mathrm{yr}$ on the Roseau main fault (for a total offset of U2 and U1 equal to $450 \mathrm{~m}$ ). Considering the end member case where the $50 \mathrm{~m}$ high Canyon segment' scarp, that is not incised by canyons, grew during the past $130 \mathrm{kyr}$, the Roseau fault slip rate would be of maximum $0.4 \mathrm{~mm} / \mathrm{yr}$. We also documented that the Holocene $\sim 10 \mathrm{ka}$-old drowned reef of Les Saintes is offset by 5-8 $\mathrm{m}$ by eastern dipping faults of the eastern system, and that sediment waves probably formed after the LGM until early Holocene are offset by 2-5 $\mathrm{m}$ by the same system. This would imply faster slip rates over the Holocene, on these secondary faults. Large uncertainties remain on faults slip rate. It might be on the order of a few tenths of $\mathrm{mm} / \mathrm{yr}$, sampling of submarine volcanoes and deposits crosscut by the faults are needed in order to better constrain the slip rate.

\subsection{Interactions Between Faulting, Sedimentary, and Mass-Wasting Processes}

Along the western slope of Les Saintes plateau, we document a turbiditic system made of canyons of different sizes and maybe generations. We clearly showed that faulting influences the canyon development, the mass-wasting processes, and the formation of small basins in which sediments are now ponding. Initiation of faulting has thus changed the sedimentary processes location and the morphology of the volcanic arc. Sedimentary processes in turn modify fault surface expression and the morphology of the scarps, which can be eroded by retrogression along canyons or buried by sediments. Identifying such two-way interactions is important to discuss fault activity and estimate properly the slip rate in order to better assess the seismic activity of a fault system and its related seismic hazard.

Faulting also enhances mass-wasting processes. We document several kilometer-wide amphitheater-shaped canyon heads resulting from multiple slumps close to the Roseau fault. Slumps can result from sediment overloading, chemical and physical changes due to oceanographic changes [Coniglio and Dix, 1992, and references therein], and are certainly favored by strong coseismic ground motion [e.g., Goldfinger et al., 2003]. Earthquakes on the Roseau segments, could initiate slope instabilities, which may further promote large tsunamis [e.g., Li et al., 2015], posing additional threats for the nearby Guadeloupean and Dominican coasts.

\section{Conclusion}

New high-resolution marine geophysical data (bathymetry, seismic reflection, backscatter images, and sidescan sonar images) acquired during the two oceanographic cruises GWADASEIS and BATHYSAINTES, allow to characterize a large normal fault system in Les Saintes channel, and to investigate the interactions between active faulting, volcanism, sedimentary and mass-wasting processes. Les Saintes fault system is composed of several normal faults that form a $30 \mathrm{~km}$ wide half-graben. The overall geometry of the fault system, as well as the distribution of volcanic edifices within the channel, are compatible with regional NESW extension. The damage zone located at the tip of the faults indicates that the fault system propagates southward. A detailed morphological study along the main fault of the system (Roseau fault), responsible for the 2004 earthquake, reveals that it is longer than previously inferred and extends over 40 km from Guadeloupe to Dominica. It could generate Mw 7 earthquakes in the future.

High-resolution bathymetry and side-scan sonar images along the major faults offer the possibility to explore their small-scale morphology. Along dip, cumulative scarps have a staircase morphology composed of metric stairs that could be strata but also coseismic scarps. Along strike, we observed different morphologies of normal fault scarps resulting from shear or hybrid failure. The mode of failure might be related to lithology differences but also to the height of the water column above the faults that controls the hydrostatic pressure applied at the seafloor.

We document and discuss relationships and feedbacks between faulting, volcanism, sedimentary and masswasting processes at several spatiotemporal scales. The fault system initiated after the main volcanic construction (Roseau volcano), and subsequently controls the emission of volcanic products. Several volcanic cones are emplaced at the tip of the fault system damage zone probably due to fissures opening in an area of stress increase. The main fault controls the development of a large turbiditic system made of kilometerwide canyons. Several faults are also responsible for sediment ponding. In turn, erosion and sedimentation 
prevent scarp growth at the seafloor. Faulting also enhance mass-wasting processes. Earthquakes could initiate slope instabilities, which may further promote large tsunamis.

Overall, the initiation and activity of the fault system has greatly influenced both the location of volcanic activity at the seafloor as well as sedimentation and erosion processes, modifying the overall morphology of the volcanic arc. These relationships constitute important information for the tectonic and volcanic evolution of a modern island arc, and must be considered when assessing its seismic, volcanic and tsunami hazard.

\section{Acknowledgments}

We thank the GENAVIR captains, officers and crew of N/O Pourquoi Pas? (Ifremer/French Navy) and N/O Le Suroit (Ifremer) and the SHOM team who operates Le Pelican hydrographic launcher. This study was supported by the ANR CATELL' RISKNAT and CNRS INSU program. We are grateful to the BATHYSAINTES and GWADASEIS scientific parties: S. Bazin, F. Beauducel, G. Boudon, V. Clément, L. De Min, J. F. Lebrun, A. Le Friant, D. Melezan, A. Nercessian, J.-M. Saurel, and to the French Seismological and Volcanological Observatories. The SAR profiles were processed with the valuable help of Jean-Marie Augustin, Delphine Pierre and Arnaud Gaillot. All data acquired during GWADASEIS and BATHYSAINTES are available on the SISMER database (http://www.ifremer. $\mathrm{fr} / \mathrm{sismer})$. We are grateful to two anonymous reviewers for their comments that helped us improving this manuscript, as well as to L. Barrier and S. Jorry for constructive discussions, and C. Goldfinger and J. Escartín for their advices. We thank P. Burgi, P. M. Morgan, and S. Pansino for proofreading. We used the GMT software developed by P. Wessel and W. Smith (available at http://www. soest.hawaii.edu/gmt/) for most of the figures. This is IPGP contribution 3743.

\section{References}

Armijo, R., et al. (2005), Submarine fault scarps in the Sea of Marmara pull-apart (North Anatolian Fault): Implications for seismic hazard in Istanbul, Geochem. Geophys. Geosyst., 6, Q06009, doi:10.1029/2004GC000896.

Bazin, S., N. Feuillet, C. Duclos, W. Crawford, A. Nercessian, M. Bengoubou-Valerius, F. Beauducel, and S. C. Singh (2010), The 2004-2005 Les Saintes (French West Indies) seismic aftershocks sequence observed with océan bottom seismometers, Tectonophysics, 489(1-4), 91-103.

Beauducel, F., et al. (2005), The Mw 6.3 earthquake of Les Saintes (Guadeloupe) on November 21, 2004, paper presented at European Seismological Commission Annual Workshop, Int. Assoc. of Volcanol. and Chem. of the Earth's Inter., Saint-Claude, Guadeloupe.

Bellier, O., and M. Sébrier (1994), Relationship between tectonism and volcanism along the Great Sumatran fault zone deduced by SPOT image analyses, Tectonophysics, 233(3), 215-231.

Bouysse, P., and P. Gennoc (1983), Données sur la structure de l'arc insulaire des Petites Antilles, entre Ste-Lucie et Anguilla, Mar. Geol., 53(1), 131-166.

Bowin, C. (1976), Caribbean Gravity Field and Plate Tectonics, Spec. Pap. Geol. Soc. Am., 169, 79.

Coniglio, M., and G. R. Dix (1992), Carbonate slopes, in edited by R. G. Walker and N. P. James, pp. 349-373, Facies Models-Response to Sea Level Change, Geological Association of Canada, Ontario.

De Chabalier, J. B., and J. P. Avouac (1994), Kinematics of the Asal Rift (Djibouti) determined from the deformation of Fieale Volcano, Science, $265,1677-1681$.

DeMets, C., P. E. Jansma, G. S. Mattioli, T. H. Dixon, F. Farina, R. Bilham, E. Calais, and P. Mann (2000), GPS geodetic constraints on Caribbean-North America plate motion, Geophys. Res. Lett., 27(3), 437-440.

Deplus, C., A. Le Friant, G. Boudon, J. C. Komorowski, B. Villemant, C. Harford, J. Ségoufin, and J. L. Cheminée (2001), Submarine evidence for large-scale debris avalanches in the Lesser Antilles Arc, Earth Planet. Sci. Lett., 192(2), 145-157.

Devès, M., S. R. Tait, G. C. P. King, and R. Grandin (2014), Strain heating in process zones; implications for metamorphism and partial melting in the lithosphere, Earth Planet. Sci. Lett., 394, 216-228.

Elias, A., et al. (2007), Active thrusting offshore Mount Lebanon: Source of the tsunamigenic AD 551 Beirut-Tripoli earthquake, Geology, $35(8), 755-758$.

Escartín, J., et al. (2016), Olive First direct observation of coseismic slip and seafloor rupture along a submarine normal fault and implications for fault slip history, Earth Planet. Sci. Lett., 450, 96-107.

Feuillet, N., I. Manighetti, and P. Tapponnier (2002), Arc parallel extension and localization of volcanic complexes in Guadeloupe, Lesser Antilles, J. Geophys. Res., 107(B12), 2331, doi:10.1029/2001JB000308.

Feuillet, N., et al. (2010), Active faulting induced by slip partitioning in Montserrat and link with volcanic activity: New Insights from the 2009 GWADASEIS marine cruise data, Geophys. Res. Lett., 37, L00E15, doi:10.1029/2010GL042556.

Feuillet, N., F. Beauducel, E. Jacques, P. Tapponnier, B. Delouis, S. Bazin, M. Vallée, and G. C. P. King (2011), The Mw =6.3, November 21, 2004, Les Saintes earthquake (Guadeloupe): Tectonic setting, slip model and static stress changes, J. Geophys. Res., 116, B10301, doi: $10.1029 / 2011 \mathrm{JB} 008310$.

Fildani, A., W. R. Normark, S. Kostic, and G. Parker (2006), Channel formation by flow stripping: Large-scale scour features along the Monterey East Channel and their relation to sediment waves, Sedimentology, 53(6), 1265-1287.

Goldfinger, C., C. H. Nelson, and J. E. Johnson (2003), Holocene earthquake records from the Cascadia subduction zone and northern San Andreas Fault based on precise dating of offshore turbidites, Annu. Rev. Earth Planet. Sci., 31(1), 555-577.

Jorry, S., A. Droxler, and J. M. Francis (2010), Deepwater carbonate deposition in response to re-flooding of carbonate bank and atoll-tops at glacial terminations, Quat. Sci. Rev., 29(17-18), 2010-2026.

Kettermann, M., and J. Urai (2015), Changes in structural style of normal faults due to failure mode transition: First results from excavated scale models, J. Struct. Geol., 74, 105-116.

Kim, Y.-S., D. C. P. Peacockm, and D. J. Sanderson (2004), Fault damage zones, J. Struct. Geol., 26(3), 503-517.

Lallemant, H. G. A., and J. S. Oldow (2000), Active displacement partitioning and arc-parallel extension of the Aleutian volcanic arc based on Global Positioning System geodesy and kinematic analysis, Geology, 28(8), 739-742.

Lebas, E., A. Le Friant, G. Boudon, S. F. L. Watt, P. J. Talling, N. Feuillet, C. Deplus, C. Berndt, and M. F. Vardy (2011), Multiple widespread landslides during the long-term evolution of a volcanic island: Insights from high-resolution seismic data, Montserrat, Lesser Antilles, Geochem. Geophys. Geosyst., 12, Q05006, doi:10.1029/2010GC003451.

Leclerc, F., et al. (2014), The Holocene drowned reef of Les Saintes plateau as witness of a long-term tectonic subsidence along the Lesser Antilles volcanic arc in Guadeloupe, Mar. Geol., 355, 115-135.

Le Friant, A., C. L. Harford, C. Deplus, G. Boudon, R. S. J. Sparks, R. A. Herd, and J. C. Komorowski (2004), Geomorphological evolution of Montserrat (West Indies): Importance of flank collapse and erosional processes, J. Geol. Soc. London, 161, 147-160.

Li, L., A. Switzer, Y. Wnag, R. Weiss, Q. Qiu, C-H. Chan, and P. Tapponnier (2015), What caused the mysterious eighteenth century tsunami that struck the southwest Taiwan coast?, Geophys. Res. Lett., 42, 8498-8506, doi:10.1002/2015GL065567.

Lindsay, J. M., A. L. Smith, M. J. Roobol, and M. V. Stasiuk (2005), Dominica. Volcanic Hazard Atlas of the Lesser Antilles, pp. 1-47, Trinidad and Tobago, The Seismic Research Unit, University of the West Indies.

López, A. M., S. Stein, T. Dixon, G. Sella, E. Calais, P. Jansma, J. Weber, and P. La Femina (2006), Is there a northern Lesser Antilles forearc block?, Geophys. Res. Lett., 33, L07313, doi:10.1029/2005GL025293.

Manighetti, I., G. C. P. King, Y. Gaudemer, C. H. Scholz, and C. Doubre (2001), Slip accumulation and lateral propagation of active normal faults in Afar, J. Geophys. Res., 106(B7), 13,667-13,696. 
Manighetti, I., G. C. P. King, and C. G. Sammis (2004), The role of off-fault damage in the evolution of normal faults, Earth Planet. Sci. Lett., 217(3), 399-408.

Manighetti, I., D. Zigone, M. Campillo, and F. Cotton (2009), Self-similarity of the largest-scale segmentation of the faults: Implications for earthquake behavior, Earth Planet. Sci. Lett., 288(3-4), 370-381.

McCaffrey R., P. C. Zwick, Y. Bock, L. Prawirodirdjo, J. F. Genrich, C. W. Stevens, S. S. O. Puntodewo, and C. Subarya (2000), Strain partitioning during oblique plate convergence in northern Sumatra: Geodetic and seismologic constraints and numerical modeling, J. Geophys. Res., 105(B12), 28,363-28,376.

McCann, W. R., J. W. Dewey, A. J. Murphy, and S. T. Harding (1982), A large normal-fault earthquake in the overriding wedge of the Lesser Antilles subduction zone: The earthquake of 8 October 1974, Bull. Seismol. Soc. Am., 72(6A), 2267-2283.

Mulder, T., et al. (2012), Canyon morphology on a modern carbonate slope of the Bahamas: Evidence of regional tectonic tilting, Geology, 40(9), 771-774

Mullins, H. T., and A. C. Hine (1989), Scalloped bank margins: Beginning of the end for carbonate platforms?, Geology, 17(1), 30-33.

Ohmachi, T., H. Tsukiyama, and H. Matsumoto (2001), Simulation of tsunami induced by dynamic displacement of seabed due to seismic faulting, Bull. Seismol. Soc. Am., 91(6), 1898-1909.

Paulatto, M., et al. (2010), Upper crustal structure of an active volcano from refraction/reflection tomography, Montserrat, Lesser Antilles, Geophys. J. Int., 180(2), 685-696.

Perrin, C., I. Manighetti, and Y. Gaudemer (2016), Off-fault tip splay networks: A genetic and generic property of faults indicative of their long-term propagation, C. R. Geosci., 348, 52-60.

Puga-Bernabéu, A., J. M. Webster, R. J. Beaman, and V. Guilbaud (2013), Variation in canyon morphology on the Great Barrier Reef margin, north-eastern Australia: The influence of slope and barrier reefs, Geomorphology, 191, 35-50.

Salichon, J., A. Lemoine, and H. Aochi (2009), Validation of teleseismic inversion of the 2004 M-w 6.3 Les Saintes, Lesser Antilles, earthquake by 3D finite-difference forward modeling, Bull. Seismol. Soc. Am., 99, 3390-3401.

Schlager, W., J. A. Austin, W. Corso, C. L. McNulty, E. Fluegel, O. Renz, and J. C. Steinmetz (1984), Early Cretaceous platform re-entrant and escarpment erosion in the Bahamas, Geology, 12(3), 147-150.

Searle, D. E., N. Harvey, D. Hopley, and D. P. Johnson (1981), Significance of results of shallow seismic research in the Great Barrier Reef province between $16^{\circ} 10^{\prime} \mathrm{S}$ and $20^{\circ} 05^{\prime} \mathrm{S}$, in Fourth Proceedings International Coral Reef Symposium, pp. 531-539, Marine Sciences Center, University of the Philippines, Manila, Philippines.

Shalev, E., et al. (2010), Three-dimensional seismic velocity tomography of Montserrat from the SEA-CALIPSO offshore/onshore experiment, Geophys. Res. Lett., 37, L00E17, doi:10.1029/2010GL042498.

Sieh, K., and D. Natawidjaja (2000), Neotectonics of the Sumatran fault, Indonesia, J. Geophys. Res., 105(B12), 28,295-28,326.

Stockwell, J. W., Jr., and J. K. Cohen (2002), The New SU User's Manual, p. 3, Cent. for Wave Phenomena, Colo. Sch. of Mines, Golden.

Tanioka, Y., and K. Satake (1996), Tsunami generation by horizontal displacement of ocean bottom, Geophys. Res. Lett., 23(8), 861-864.

Wallace, R. E. (1977), Profiles and ages of young fault sxarps, north-central Nevada, Geol. Soc. Am. Bull., 88(9), 1267-1281.

Wells, D. L., and K. J. Coppersmith (1994), New empirical relationships among magnitude, rupture length, rupture width, rupture area, and surface displacement, Bull. Seismol. Soc. Am., 84(4), 974-1002.

Wynn, R. B., and D. A. V. Stow (2002), Classification and characterization of deep-water sediment waves, Mar. Geol., $192,7-22$.

Wynn, R. B., P. J. W. Piper, and M. J. R. Gee (2002), Generation and migration of coarse-grained sediment waves in turbidity current channels and channel-lobe transition zones, Mar. Geol., 192(1), 59-78.

Wynn, R. B., D. G. Masson, D. A. V. Stow, and P. P. E. Weaver (2000), Turbidity current sediment waves on the submarine slopes of the western Canary Islands, Mar. Geol., 163(1), 185-198.

Zami, F., X. Quidelleur, J. Ricci, J.-F. Lebrun, and A. Samper (2014), Initial sub-aerial volcanic activity along the central Lesser Antilles inner arc: New K-Ar ages from Les Saintes volcanoes, J. Volcanol. Geotherm. Res., 287, 12-21. 